\title{
Coupling of the spatial dynamic of picoplankton and nanoflagellate grazing pressure and carbon flow of the microbial food web in the subtropical pelagic continental shelf ecosystem
}

K.-P. Chiang ${ }^{1,2}$, A.-Y. Tsai ${ }^{1}$, P.-J. Tsai ${ }^{1}$, G.-C. Gong ${ }^{1,2}$, and S.-F. Tsai ${ }^{1}$

${ }^{1}$ Institute of Marine Environmental Chemistry and Ecology, National Taiwan Ocean University, Keelung 202-24, Taiwan

${ }^{2}$ Center of Excellence for Marine Bioenvironment and Biotechnology, National Taiwan Ocean University, Keelung 202-24, Taiwan

Received: 29 November 2012 - Accepted: 30 November 2012 - Published: 7 January 2013

Correspondence to: K.-P. Chiang (kpchiang@mail.ntou.edu.tw)

Published by Copernicus Publications on behalf of the European Geosciences Union.

Coupling of the spatial dynamic of picoplankton and nanoflagellate

K.-P. Chiang et al.

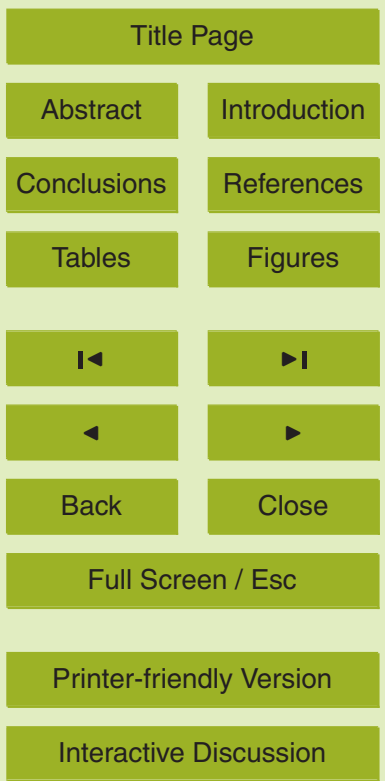




\section{Abstract}

In order to investigate the mechanism of spatial dynamics of picoplankton community (bacteria and Synechococcus spp.) and estimate the carbon flux of the microbial food web in the oligotrophic Taiwan Warm Current Water of subtropical marine 5 pelagic ecosystem, we conducted size-fractionation experiments in five cruises by the R/V Ocean Research // during the summers of 2010 and 2011 in the southern East China Sea. We carried out culture experiments using surface water which, according to a temperature-salinity $(T-S)$ diagram, is characterized as oligotrophic Taiwan Current Warm Water. We found a negative correlation bettween bacteria growth rate induced by nutrients lifted from deep layer by cold upwelling water. This finding sug gests that the area we studied was a bottom-up control pelagic ecosystem. We suggest that the microbial food web of an oligotrophic ecosystem may be changed from top-down control to resource supply (bottom-up control) when a physical force brings photic zone and promotes bacteria growth, increasing the picoplankton biomass which increased the consumption rate of nanoflagellate. The net growth rate (growth rategrazing rate) becomes negative when the densities of bacteria and Synechococcus spp. are lower than the threshold values. The interaction between growth and graz20 ing will limit the abundances of bacteria $\left(10^{5}-10^{6}\right.$ cells $\left.\mathrm{mL}^{-1}\right)$ and Synechococcus spp. $\left(10^{4}-10^{5}\right.$ cells $\left.\mathrm{mL}^{-1}\right)$ within a narrow range, forming a predator-prey eddy. Meanwhile, $62 \%$ of bacteria production and $55 \%$ of Synechococcus spp. production are transported to higher trophic level (nanoflagellate), though the cascade effect might cause an underestimation of both percentages of transported carbon. Based on the 25 increasing number of sizes we found in the size-fractionation experiments, we estimated that the predation values were underestimated by $28.3 \%$ for bacteria and $34.6 \%$ for Synechococcus spp. Taking these corrections into consideration, we conclude that

\section{BGD}

10, 233-263, 2013

\section{Coupling of the spatial dynamic of picoplankton and nanoflagellate}

K.-P. Chiang et al.

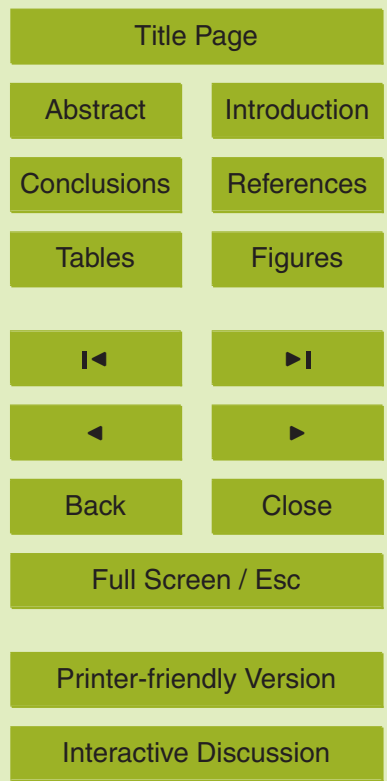


picoplankton production is balanced by nonoflagellate grazing and the diet of nanoflagellate is composed of $64 \%$ bacteria and $36 \%$ Synechococcus spp.

\section{Introduction}

Bacteria are very important energy and carbon sources in the marine pelagic ecosys5 tem (Pomeroy, 1974; Azam et al., 1983). The transfer of bacterial organic carbon to higher trophic level in a linear food chain via bacteria, nanoflagellates, and ciliates was formalized as the "microbial loop" (Azam et al., 1983). When picophytoplankton was added as a primary producer, this loop became to be referred to as a complex "microbial food web" (Sherr and Sherr, 1994). Picoplankton, including heterotrophic bacteria and picophytoplankton (Prochlorococcus, Synechococcus and picoeukaryotes), are generally thought to be consumed mainly by nanoflagellates in a marine pelagic ecosystem. Our previous studies demonstrated that bacteria were mostly consumed by nanoflagellates of size $<6 \mu \mathrm{m}$, and Synechococcus was consumed mainly by pigmented nanoflagellates of 3-10 $\mu \mathrm{m}$ in subtropical western Pacific coastal ecosystem 15 (Chan et al., 2009; Tsai et al., 2011).

Factors that regulate the standing stock of picoplankton include bottom-up control on the growth environment (temperature, nutrients, and substrate supply) (Almeida et al., 2001; Schultz Jr. et al., 2003; Ameryk et al., 2005) as well as top-down mortality pressure, especially grazing and viral lysis (Wilhelm et al., 2002; Taira et al., 2009).

With regard to marine systems, there is an ongoing debate on whether the standing stock and production of picoplankton are mainly controlled by bottom-up or top-down mechanisms. The close coupling between picoplankton and bacterivores in experiments were used initially as evidence of top-down control by protistan grazer (Ducklow, 1983; Tanaka et al., 1997; Calbet et al., 2001; Hirose et al., 2008). The positive cor-
BGD

$10,233-263,2013$

\section{Coupling of the spatial dynamic of picoplankton and nanoflagellate}

K.-P. Chiang et al.

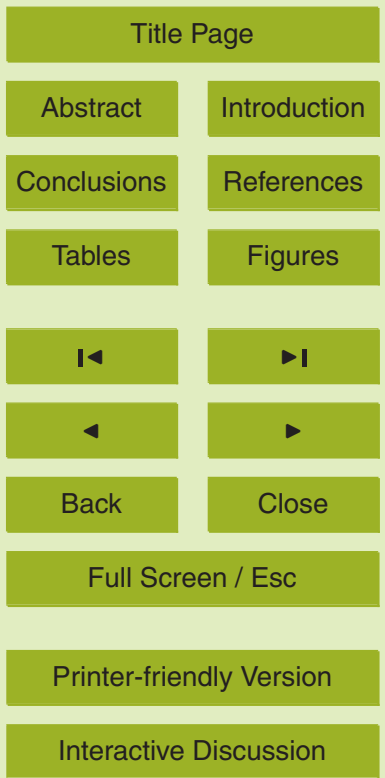


addition, many empirical models have drawn conclusions on the relative importance of top-down and bottom-up controls by referring to the slope of the regression between bacteria production and bacteria biomass (Ducklow, 1992), to the coupling between the abundance of bacteria and their main predator (heterotrophic nanoflagellate; 5 Gasol 1994; Gasol et al., 2002), and to the relationship between bacteria growth rate and bacteria abundance (Wright and Coffin, 1984; Zubkov et al., 2000; Jochem, 2003). Studies applying several of these methods to the marine pelagic ecosystem have concluded that bacteria are commonly regulated top-down in most oligotrophic situations and regulated bottom-up in eutrophic environments (Gasol et al., 2002).

10 Generally, bacteria have high growth rates in both marine and freshwater environments, yet their growth is often balanced by the effect of predation, e.g., nanoflagellate grazing (Sanders et al., 1992; Zubkov et al., 2000; Vaqué et al., 2002; Tsai et al., $2005,2008)$. Therefore, bacterial abundance is less spatially and temporally variable and remarkably constant (Cole and Caraco, 1993; Tsai et al., 2005). Nanoflagellate abundance, on the other hand, has marked seasonal fluctuation (Tanaka et al., 1997; Tanaka and Taniguchi, 1999; Granda and Álvarez, 2008). Tanaka et al. (1997) proposed a predator-prey eddy to illustrate the temporal variation in the numerical relationship between nanoflagellate and bacteria. On annual scales, the position and magnitude of the eddy differed between seasons due to changes in environmental conditions. It has been hypothesized that the formation of the predator-prey eddy is promoted by nanoflagellate grazing process (Tanaka and Taniguchi, 1999). However, we know little about how growth and mortality rates regulate the spatial dynamic of bacterial community and the predator-prey eddy does little to explain this relationship.

This study investigated the impact of the substrate supply and the grazing of nanoflagellate on picoplankton communities in an oligotrophic pelagic marine ecosystem (Taiwan Warm Current Water) of the subtropical western Pacific during the summer season (June to September). We investigate the existence of a predator-prey eddy of nanoflagellate-bacteria association in spatial scale and identify the mechanisms underlying the formation of predator-prey eddy.

BGD

10, 233-263, 2013

\section{Coupling of the spatial dynamic of picoplankton and nanoflagellate}

K.-P. Chiang et al.

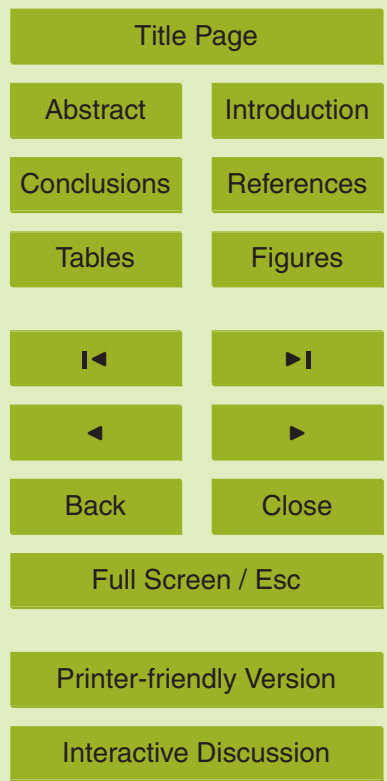




\section{Materials and methods}

\subsection{Sampling}

BGD

Samples were collected during five cruises of the R/V Ocean Research II in the summers of 2010 and 2011 at 12 stations crossing the continental shelf in the southern East

5 China Sea (ECS) (Fig. 1). Seawater for microscopic counting of picoplankton (bacteria and Synechococcus spp.) and nanoflagellate was collected by Sea Bird CTD-General Oceanic Rosette assembly with $20 \mathrm{~L}$ Go-Flo bottles at six water depths $(5,10,25,50$, 75 and $100 \mathrm{~m}$ ). Temperature and salinity profiles were taken from the surface to near bottom using a Sea Bird CTD-General Oceanic Rosette.

\subsection{Flow cytometric analysis of picoplankton}

Each $2 \mathrm{~mL}$ subsample used in the flow cytometry analyses was fixed with $40 \mu \mathrm{L}$ paraformaldehyde $(0.2 \%$ final concentration), quickly frozen in liquid nitrogen, and stored in a freezer at $-75^{\circ}$ for later analysis (Campbell and Vaulot, 1993). Abundances of picoplankton (heterotrophic bacteria and Synechococcus spp.) were determined by

15 flow cytometry (Marie et al., 1997) using an FACSAria flow cytometer (Becton Dickinson). Samples were run on the low rate setting for $2 \mathrm{~min}$. Synechococcus spp. specimens were distinguished according to their positions in plots of orange fluorescence (FL2) and red fluorescence (FL3). Bacteria were identified by using SYBR Green I (Molecular Probes) as a nucleic acid stain (Marie et al., 1997) for in a plot of fluorescence FL3 versus green fluorescence (FL1). Internal calibration beads ( $1 \mu \mathrm{m}$ yellowgreen fluorescence beads) were added to each sample as an internal reference.

\subsection{Epifluorescence microscopic analysis of nanoplankton}

For enumeration of nanoplankton, $50 \mathrm{~mL}$ water samples were fixed with glutaraldehyde to a final concentration of $1 \%$ (Christaki et al., 2002; Sanders et al., 2000). Subsam-

ples ( $20 \mathrm{~mL}$ each) for pigmented and non-pigmented cells were filtered onto a $0.8 \mu \mathrm{m}$

\section{Coupling of the spatial dynamic of picoplankton and nanoflagellate}

K.-P. Chiang et al.

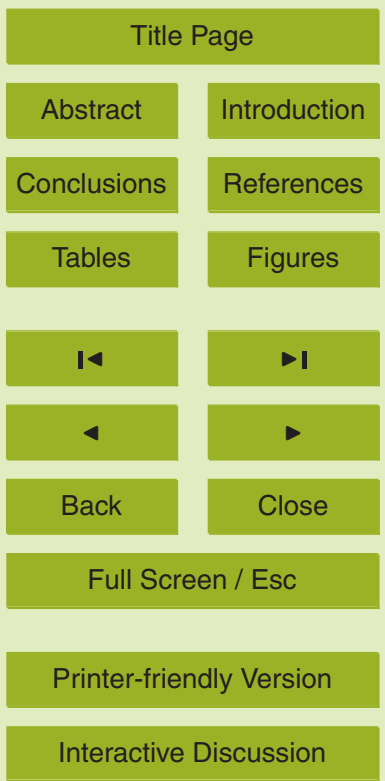


black Nuclepore filter under low pressure $(<100 \mathrm{mmHg})$ with a $0.45 \mu \mathrm{m}$ pore size Millipore filter used as a backing-pad to obtain an even distribution of cells. The cells left on the filter membranes were stained with 4'6-diamidino-2-phenylindole (DAPI) at a final concentration of $1 \mathrm{\mu g} \mathrm{mL}^{-1}$ (Porter and Feig, 1980) and counted under epifluorescence 5 microscope at $1000 \times$ (Nikon Optiphot-2). Non-pigmented nanoflagellates were identified by their blue fluorescence under UV illumination, and pigmented nanoflagellates were identified by their orange and red autofluorescence under blue excitation light. To obtain reliable estimates of abundance, at least 100 nanoflagellates were counted per sample.

\subsection{Growth and grazing rates}

The growth and grazing rates were estimated using fractionation method (Wright and Coffin, 1984) at seven stations, including two coastal stations (St. 1 and 2), two middle stations usually influenced by oligotrophic Taiwan Current Warm Water (St. 5 and 6), and three offshore stations often affected by Kuroshio Upwelling Water (St. 9 and 10 or 11) (Gong et al., 1996). At each station, surface seawater sample was collected. One subsample ( $500 \mathrm{~mL}$ each) was filtered through a $2 \mu \mathrm{m}$ pore size polycarbonate membrane to remove predators of bacteria and Synechococcus spp.; another through a $10 \mu \mathrm{m}$ pore size polycarbonate membrane to remove predators of nanoflagellates. Each size fraction was then transferred into polycarbonate bottles of $500 \mathrm{~mL}$ (run in 20 triplicate). The subsamples were incubated in a water bath at in situ temperature and light intensity for $24 \mathrm{~h}$. At the beginning and end of each incubation period, triplicate samples $(30 \mathrm{~mL})$ were taken to count the number of pico- and nanoplankton as described above.

Growth rates $\left(\mu, \mathrm{d}^{-1}\right)$ of bacteria and Synechococcus spp. $\left(\mu, \mathrm{d}^{-1}\right)$ were calculated 25 on the basis of the results from the $<2 \mu \mathrm{m}$ filtrates, and those of nanoflagellates were calculated from the $<10 \mu \mathrm{m}$ filtrates according to the following equation:
BGD

10, 233-263, 2013

Coupling of the spatial dynamic of picoplankton and nanoflagellate

K.-P. Chiang et al.

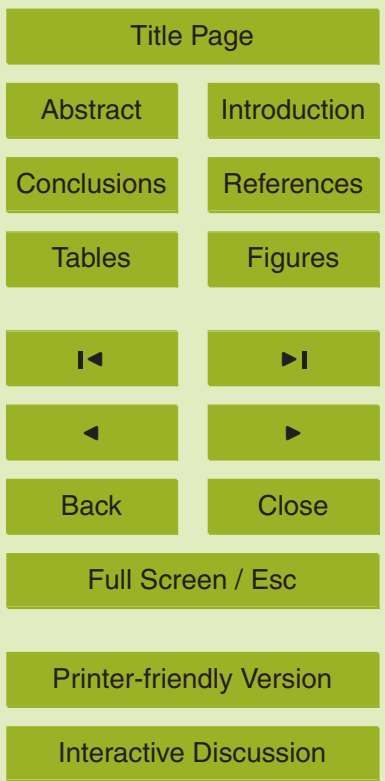


$\mu=\frac{\left(\ln N_{f}-\ln N_{i}\right)}{\left(T_{f}-T_{i}\right)}$

BGD

where $N_{i}$ and $N_{f}$ are cell numbers at the initial $\left(T_{\mathrm{i}}\right)$ and final $\left(T_{\mathrm{f}}\right)$ incubation time corresponding to size fractions.

Grazing rates of nanoflagellate on bacteria and Synechococcus spp. $\left(g, \mathrm{~d}^{-1}\right)$ were 5 obtained from the difference of growth rate between the $<2 \mu \mathrm{m}$ filtrates and the $<10 \mu \mathrm{m}$ filtrates based on the following equation:

$g=\mu_{2} \mu \mathrm{m}-\mu_{10} \mu \mathrm{m}$

Microbial abundance was converted into carbon biomass $\left(B, \mu \mathrm{g} \mathrm{CL^{-1 }}\right)$ according to the conversion coefficient of $20 \mathrm{fg} \mathrm{C} \mathrm{cell}^{-1}$ for bacteria (Lee and Fuhurman, 1987),

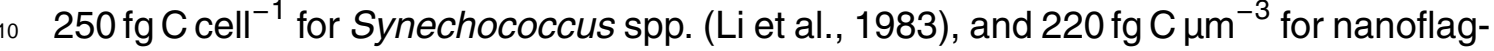
ellates (Børsheim and Bratbak, 1987). For cell volume of nanoflagellates, linear dimensions (length and width) of at least 20 cells were measured in each sample, and the cell volume was calculated as an elliptical sphere.

Production rates $\left(P, \mu \mathrm{g} \mathrm{L} \mathrm{L}^{-1} \mathrm{~d}^{-1}\right)$ of bacteria and Synechococcus spp. were estimated from the $<2 \mu \mathrm{m}$ filtrates using the following equation:

$P=\mu \times B_{i}$

where $B_{i}$ is the in situ cell biomass $\left(\mu \mathrm{g} \mathrm{CL}^{-1}\right)$ at the sampling time $i$. Production rates ( $\mathrm{mg} \mathrm{CL}^{-1} \mathrm{~d}^{-1}$ ) of nanoflagellates were similarly estimated in the $<10 \mu \mathrm{m}$ filtrates.

Consumption rates of nanoflagellates $\left(G, \mu \mathrm{g} \mathrm{L}^{-1} \mathrm{~d}^{-1}\right)$ on picoplankton (bacteria or Synechococcus spp.) were calculated according to the following equation:

$G=g \times B_{i}$

10, 233-263, 2013

\section{Coupling of the spatial dynamic of picoplankton and nanoflagellate}

K.-P. Chiang et al.

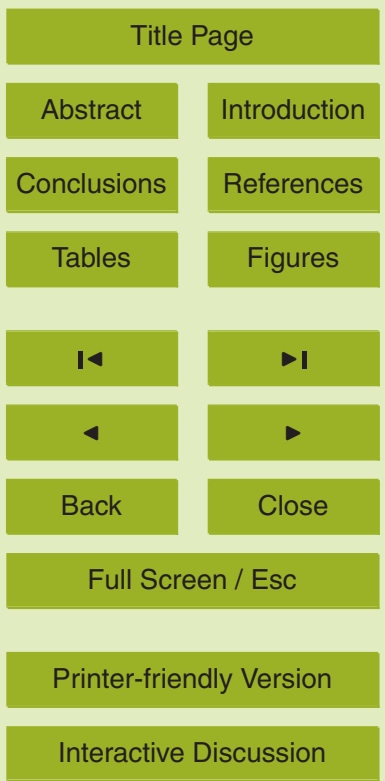




\section{Results}

Spatial changes in temperature and salinity observed during the summer period of 2010 and 2011 are shown in Fig. 2 and Table 1. There was no significant difference in distribution patterns of temperature and salinity through the water column between 5 the five cruises. The distribution pattern of water mass in summer remained typical in southern ECS. Throughout the surface water column water temperature was high and salinity low $\left(>25^{\circ},<34 \mathrm{psu}\right)$, and under the surface layer of offshore stations (St. 812) was Kuroshio subsurface upwelling water $\left(<22^{\circ},>34.5 \mathrm{psu}\right)$. The upwelling water reached the surface layer or intruded into the coastal area (St. 1-3) along the shelf bottom. We conducted size-fractionation experiments with samples collected from seven stations to measure the growth and grazing rates of nanoplankton at surface waters characterised, according to $T-S$ diagram, as Taiwan Current Warm Water during the study period (Fig. 3; Gong et al., 1996).

Throughout the whole water column, abundnce of bacteria and Synechococcus spp. 15 ranged between $7 \times 10^{3}-3.5 \times 10^{6}$ cells mL ${ }^{-1}$ and $<2.2 \times 10-4.7 \times 10^{5}$ cells mL $^{-1}$, respectively. Both picoplankton abundances were different, though not significant, between cruises or stations of the same cruise, showing high abundance in surface layer and no close relationship with water mass. Nanoflagellate abundance ranged between $1.7 \times 10-1.5 \times 10^{3}$ cells $\mathrm{mL}^{-1}$, and varied less than picoplankton. In samples collected from surface water, bacteria and Synechococcus spp. abundance ranged from $1.33 \times 10^{4}$ to $3.3 \times 10^{6}$ cells $\mathrm{mL}^{-1}$ and from $1.0 \times 10^{3}$ to $4.4 \times 10^{5}$ cells mL $^{-1}$, respectively, showing a spatial and temporal variation of 2 orders of magnitude (Fig. 4 ; Table 1). Nanoflagellate ranged from $6.2 \times 10$ to $1.04 \times 10^{3}$ cells mL $^{-1}$, and varied within 1 order of magnitude. It was found to be more abundant in Taiwan Current Warm Water than in Kuroshio Water (Fig. 4; Table 1).

Growth rate of bacteria and grazing rate of nanoflagellates on bacteria ranged from 0.22 to $1.99 d^{-1}$ and from -0.40 to $1.77 d^{-1}$, respectively. Bacteria growth rate was negatively correlated with temperature (Fig. 5), suggesting that the active growth of
BGD

10, 233-263, 2013

Coupling of the spatial dynamic of picoplankton and nanoflagellate

K.-P. Chiang et al.

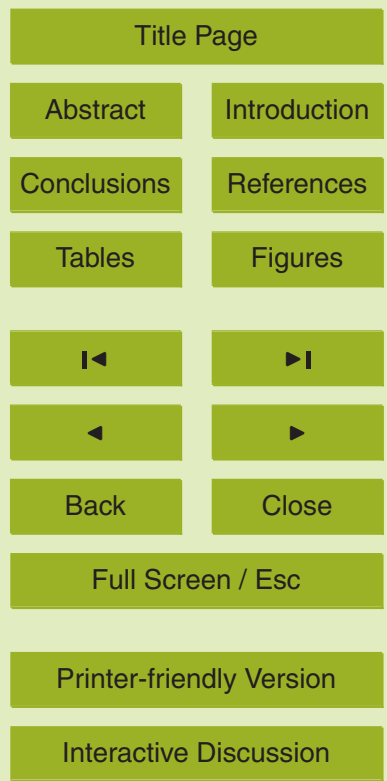


heterotrophic bacteria might occur under the influence of cold upwelling water. The growth rate of Synechococcus spp. and grazing rate of nanoflagellate on Synechococcus spp. ranged from 0.21 to $4.84 \mathrm{~d}^{-1}$ and from -0.30 to $1.33 \mathrm{~d}^{-1}$, respectively. The growth rate was not affected by upwelling water. Comparing picoplankton growth rates 5 and nanoflagellate grazing rates, we found a positive relationship between bacteria growth and nanoflagellate grazing (Fig. 6). The high bacteria growth rate corresponded with the high nanoflagellate grazing rate $(p<0.05)$. This study found a weak coupling relationship between Synechococcus growth rate and nanoflagellate grazing rate $(p>0.05$; Fig. 6). However, the spatial variations in picoplankton growth rate showed a 10 negative relationship with picoplankton abundance (Fig. 7), and nanoflagellate grazing rate showed no significant correlation with picoplankton abundance. A negative relationship between net growth rate and abundance in picoplankton was found (Fig. 8).

The production rate of bacteria varied between $1.13 \mu \mathrm{CL}^{-1} \mathrm{~d}^{-1}$ and $58.77 \mu \mathrm{g} \mathrm{CL}^{-1} \mathrm{~d}^{-1}$ (mean $21.81 \mu \mathrm{g} \mathrm{CL}^{-1} \mathrm{~d}^{-1}$ ) and consumption rates of nanoflag15 ellates on bacteria ranged from $-2.30 \mu \mathrm{gCL}^{-1} \mathrm{~d}^{-1}$ to $46.33 \mu \mathrm{gCL}^{-1} \mathrm{~d}^{-1}$ (mean $21.81 \mu \mathrm{gCL}^{-1} \mathrm{~d}^{-1}$ ). Both rates showed a close positive correlation with a slope of $0.61 \quad(p<0.05$; Fig. 9). A similar positive relationship was also found between the production rate of Synechococcus spp. $\left(1.85-32.02 \mu \mathrm{g} \mathrm{CL}^{-1} \mathrm{~d}^{-1}\right.$, mean $12.12 \mu \mathrm{g} \mathrm{C} \mathrm{L}^{-1} \mathrm{~d}^{-1}$ ) and consumption rates of nanoflagellates on Synechococcus spp. $20 \quad\left(-0.97-45.26 \mu \mathrm{g} \mathrm{CL}^{-1} \mathrm{~d}^{-1}\right.$, mean $5.22 \mu \mathrm{C} \mathrm{L}^{-1} \mathrm{~d}^{-1}$ ) with a slope of 0.55 (Fig. 9).

To characterize the interaction of trophic coupling between picoplankton and nanoflagellates and to estimate the growth rate and grazing rate of picoplankton in the presence of nanoflagellates of different sizes, successive size-fractionation experiments were undertaken in three cruises from June 2011 to September 2006. We truncated the food web by removing organisms in different body sizes $(<2 \mu \mathrm{m},<5 \mu \mathrm{m}$, $<10 \mu \mathrm{m}$, and $<20 \mu \mathrm{m}$ ) (Lin et al., 2009). Our studies have found the trophic cascade effect (e.g., St. 5 of July 2011) and nanoflagellates of size 10-20 $\mu \mathrm{m}$ were the main grazers at some stations (e.g., St. 1 of July 2011) (Fig. 11).

\section{BGD}

10, 233-263, 2013

\section{Coupling of the spatial dynamic of picoplankton and nanoflagellate}

K.-P. Chiang et al.

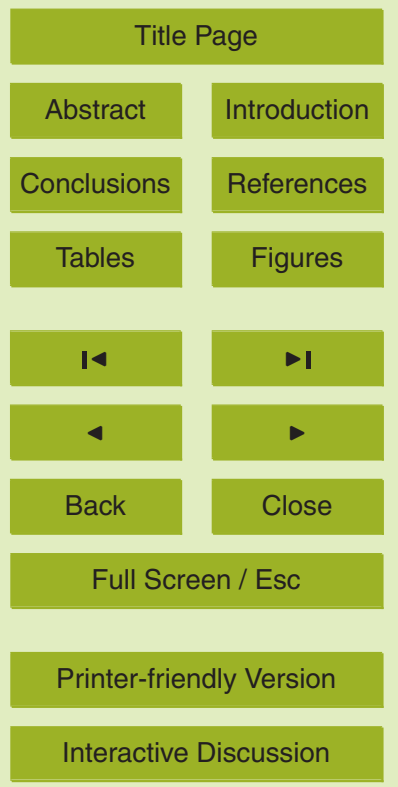




\section{Discussion}

Our study of the environment variables in the southern ECS suggest that the marine environment is a typical summer water column. A warm oligotrophic Taiwan Current Warm Water intruded into the southern ECS from the Taiwan Strait and affected the 5 pelagical ecosystem throughout the surface water column in aread we studied. A persistent upwelling system, located at the offshore near Kuroshio, is known to be a major nutrient source. The uplifted depth of the upwelling in summer is controlled by the intensity of southwestern monsoon, which brings a strong Taiwan Strait Warm Current that suppresses the lifting of upwelling water to the surface water column (Gong et al.,

\subsection{Bottom-up versus top-down control of picoplankton}

There have been some discussion regarding whether planktonic bacteria abundance is controlled by resource supply such as organic carbon or inorganic nutrient (bottom-up control) or by predation of bacterivores (top-down control) (Sander et al., 1992; Simek

et al., 1995; Lee et al., 2001; Murrell, 2003; Bouvy et al., 2004). The relative importance of population regulation is an old topic with many arguments for and against both types of control mechanisms, with the degree of this importance varing by location and period of time (Goosen et al., 1997; Ferrier-Pagés and Gattuso, 1998). However, no theory about the regulation of bacterial stock and production in pelagic ecosystem has

been universally accepted (Hariston et al., 1960; Thingstad, 2000). The positive correlations between bactera abundance and phytoplankton, dissolved organic carbon, or inorganic nutrient were used initially as evidence of bottom-up control, and, based on these correlations, conclusions were drawn regarding the prevailing control model in a given ecosystem (Billen et al., 1990; Gasol et al., 2002; Gasol and Duarte, 2000; Duarte and Agustí, 2005; Tsai et al., 2010). In the southern ECS, we found the spatial variation of heterotrophic bacteria abundance at the surface water during summer to be within a narrow range, between $5 \times 10^{4}$ and $3.3 \times 10^{6}$ cells $\mathrm{mL}^{-1}$. This range is

BGD

$10,233-263,2013$

Coupling of the spatial dynamic of picoplankton and nanoflagellate

K.-P. Chiang et al.

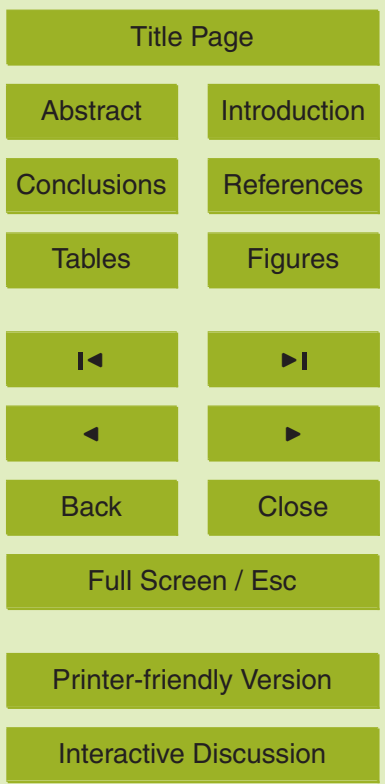


equivalent to the feeding threshold for nanoflagellate on bacteria (e.g., Fenchel et al., 1982; Andersen and Fenchel, 1985; Wikner and Hagström, 1991). Our study found high bacteria growth rates to occur under low temperatures, hence spatial variability in growth rate of heterotrophic bacteria was negatively influenced by temperature 5 (Fig. 5). This relationship was unexpected because bacteria abundance and production in aquatic ecosystems have been shown to vary positively with temperature (Hoch and Kirchman, 1993; Shiah and Ducklow, 1997; Schultz Jr. et al., 2003) and the importance of temperature as a positive regulator of marine bacteria growth rate is well recognized (White et al., 1991; Tsai et al., 2005, 2008). The low temperature we found 10 suggested that the waters we studied were affected by Kuroshio Upwelling Water. The active growth of heterotrophic bacteria might have been induced by nutrient brought upward by the cold upwelling water, indicating possible bottom-up control. However, we did not observe a significant relationship between the growth rate of Synechoccous spp. and temperature, suggesting that the cold upwelling water did not influence the 15 Synechoccous spp. community. In addition, we found a negative correlation between growth rate and abundance in bacteria (Fig. 7). Based on the density-dependent logistic growth of bacteria, Wright and Coffin (1984) used an empirical model relating bacteria growth rate with bacteria abundance to estimate the ecological state of bacteria in a given system. When their abundance was close to the carrying capacity, bacteria were limited by resource availability (bottom-up control), a negative relationship between bacteria growth rate and abundance appeared. Generally, bacteria growth appears to be top-down control in most nutrient-poor environments and bottom-up control in eutrophic environments (Gasol et al., 2002). The results of our study are in accordance with this relationship and demonstrate that abundance of resource-dependent bacteria is common in oligotrophic Taiwan Current Warm Water, where influence of high-nutrient upwelling water is prevailing. In other words, the abundance of bacteria is generally regulated by predators in most oligotrophic environments, but may be ameliorated with a sustained resource supply, e.g., from the upwelling system. Our study illustrates that the microbial food web of an oligotrophic ecosystem may be changed

BGD

10, 233-263, 2013

Coupling of the spatial dynamic of picoplankton and nanoflagellate

K.-P. Chiang et al.

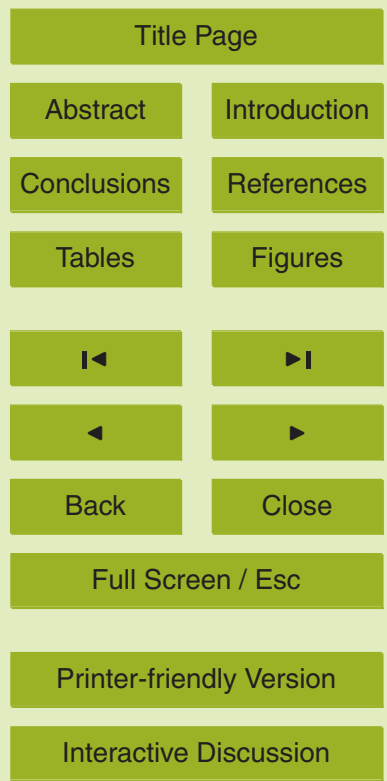


from top-down control to resource supply (bottom-up control) with the presence of a physical force to bring nutrient into the oligotrophic ecosystem.

BGD

\subsection{Spatial relation of predator-prey eddy in picoplankton and nanoflagellate}

Tanaka et al. (1997) and Tanaka and Taniguchi (1999) proposed predator-prey eddy to 5 describe the temporal variation in the numerical relationship between nanoflagellates and bacteria. In that model, tightly and stably coupled relationships between two components of abundance are confined within a narrow range on short temporal scales and continuously migrate over a certain region with season-bearing-environment factors. Based on the spatial data sets obtained within oligotrophic Taiwan Current Warm Water in summer, we plotted nanoflagellate abundance against bacteria abundance in a phase space (Fig. 4). Data sets of each cruise showed a circular orbit roughly similar to the graphic diagrams in Tanaka et al. (1997) and Tanaka and Taniguchi (1999). Location and magnitude of the orbits were clearly different between the five cruises, so these eddies were confined to a narrow range in spite of sporadic and drastic change of environmental variables. The observed circular orbits, however, sometimes showed wide protrusion where the bacteria abundance had a low density due to the cold upwelling water. Our results support the Tanaka et al. (1997) postulation that the predator-prey eddy of the nanoflagellate-bacteria system also exists in subtropical marine ecosystem and that the eddy can be shown on spatial basis, if it has similar environment condition.

20 No adequate explanation has been given regarding the mechanism underlying the predator-prey eddy in the nanoflagellate-bacteria system. Tanaka and Taniguchi (1999) suggested that the formation of the predator-prey eddy can be explained by both the intensive feeding by nanoflagellate on increasing bacteria and the inability of nanoflagellate to feed on bacteria if its concentration is lower than feeding threshold value. In munities were affected by both growth and grazing rates. The abundances of bacteria, Synechococcus spp., and nanoflagellates clearly varied within a narrow range. However, the spatial variations in picoplankton growth rate showed a negative relationship

\section{Coupling of the spatial dynamic of picoplankton and nanoflagellate}

K.-P. Chiang et al.

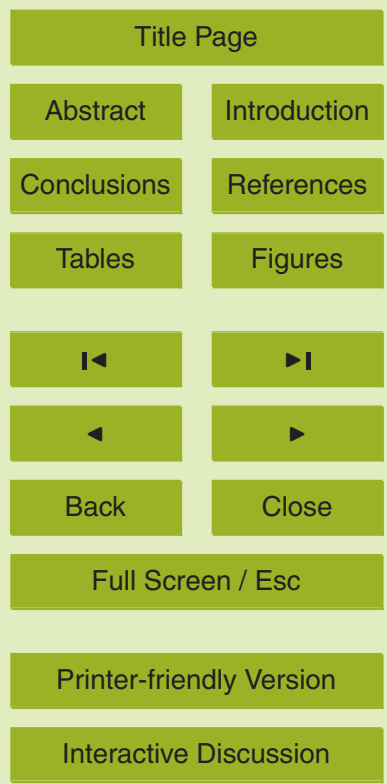


with picoplankton abundance (Fig. 7), and nanoflagellate grazing rate showed no significant correlation with picoplankton abundance. Growth rates of both picoplankton (bacteria and Synechococcus spp.) decreased with increasing picoplankton abundance, while picoplankton production rate continuously increased due to the increase 5 of picoplankton biomass $\left(P=\mu \times B_{i}\right)$, resulting in a gradual increase in picoplankton production. Moreover, while nanoflagellate grazing rate was not significantly correlated with prey, the consumption rate of nanoflagellates also was enhanced due to increased picoplankton biomass $\left(G=g \times B_{i}\right)$. Therefore, both picoplankton production rate and consumption rate increase following the increase in picoplankton biomass. In 10 fact, the predator-prey eddy of the nanoflagellate-picoplankton system is a reflection of the changing net growth rates (growth rate - grazing rate). We found a negative relationship between net growth rate and picoplankton abundance (Fig. 8). The highest net growth rates for both bacteria and Synechococcus spp. occurred when the respective abundance was lowest, and the net growth rate sharply decreased following 15 the increases in abundances of the bacteria and Synechococcus spp. communities. Subsequently, the net growth rate became negative after abundance reached a density smaller than the threshold value. The abundances of bacteria and Synechococcus spp. consequently declined (Fig. 8).

Based on these findings, the observed spatial variations in abundance (predatorprey eddy) can be explained by a scenario in which both picoplankton growth and nanoflagellate grazing influence the dynamics of the bacteria and Synechococcus spp. communities. In addition, the growth rate of picoplankton is controlled by its abundance or upwelling water. Under low temperature or low picoplankton abundance, the active growth of heterotrophic bacteria might be induced by nutrient brought upward by the cold upwelling water. Upwelling brings nutrient-rich and low-abundance water to euphotic zone with high temperature, and promotes picoplankton growth, consequently increasing abundance. When abundances reach the threshold value of picoplankton abundance, the growth rate and grazing rate are in balance, and the net growth rate approaches zero. When prey abundances exceed the threshold value, the rate of grazing

\section{BGD}

10, 233-263, 2013

\section{Coupling of the spatial dynamic of picoplankton and nanoflagellate}

K.-P. Chiang et al.

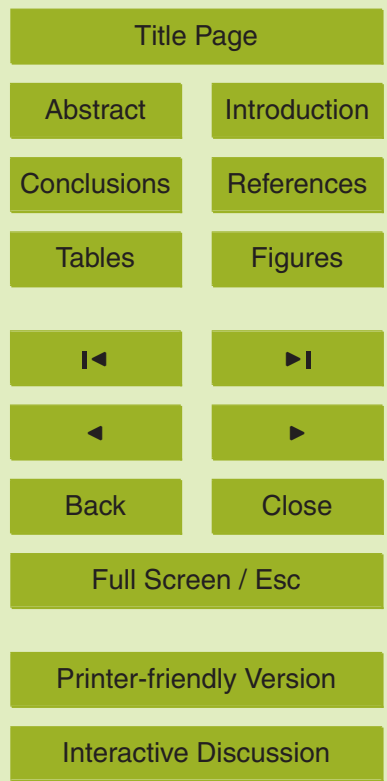


upon them increases and exceedes their growth rate, and their net growth rate becomes negative. Hence, the abundance of bacteria and Synechococcus spp. gradually decreases. This scenario has also been used to describe seasonal dynamic of picoplankton community by Tasi et al. (2008) and Kobari et al. (2010).

\section{4.3 Carbon flow in microbial food web in the oligotrophic Taiwan Strait Warm Current Water}

If bacteria production is not balanced by grazing, other factors that can cause bacterial loss, such as cell death, viruses, and sedimentation (Pace, 1988), may account for the imbalance. In our study, there was an clear imbalance between picoplankton growth and grazing, and the consumption of nanoflagellate accounted for the removal of about $62 \%$ of bacteria production and $55 \%$ of Synechococcus spp. production, respectively. We, therefore, suggest that nanoflagellates are major consumers of picoplankton (Fig. 9).

Nanoflagellates are known to potentially be able to regulate the production and abundance of picoplankton and are, therefore, thought to play a key role in the transfer of picoplanktonic carbon to higher trophic levels (Hahn and Hofle, 2001; Tsai et al., 2005). This study evaluated the dynamics of bacteria, Synechococcus spp., and nanoflagellates affecting the energy flow in the microbial food web in an oligotrophic subtropical pelagic marine ecosystem. For bacteria, the production and grazing carbon fluxes 20 ranged from 1.13 to 58.77 and -2.30 to $46.33 \mu \mathrm{g} \mathrm{CL}^{-1} \mathrm{~d}^{-1}$, respectively; likewise for Synechococcus spp., these ranges were 1.85 to 32.02 and -0.97 to $45.26 \mathrm{\mu g} \mathrm{Cl}^{-1} \mathrm{~h}^{-1}$, respectively. We also found that $64 \%$ and $36 \%$ of carbon consumed by nanoflagellates came from bacteria and Synechococcus spp., respectively. A significant part of bacteria and Synechococcus spp. carbon was channeled through the microbial food web, levels (Fig. 10).

Due to the trophic cascade effect (e.g., St. 5 of July 2011) and the main grazers of nanoflagellates of size $10-20 \mu \mathrm{m}$, the consumption rate of nanoflagellate could be
BGD

10, 233-263, 2013

Coupling of the spatial dynamic of picoplankton and nanoflagellate

K.-P. Chiang et al.

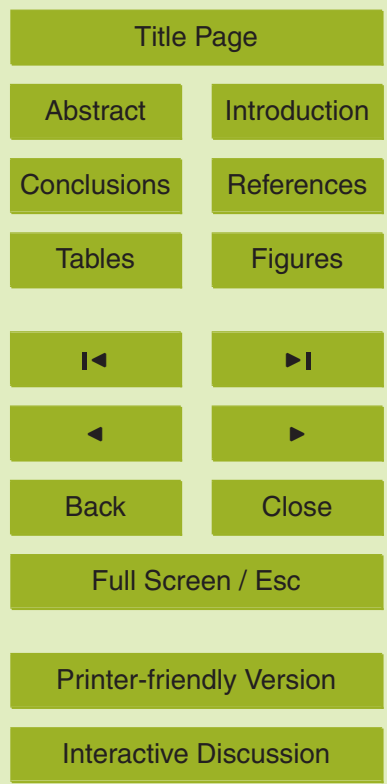


underestimated (Fig. 11). We tried to correct the grazing rate of nanoflagellate by the maximum grazing rate in three treatments of successive size-fraction experiments. The corrected result showed that the consumption rate of nanoflagellate could be underestimated about $28.3 \%$ for bacteria and $34.6 \%$ for Synechococcus spp., respectively. 5 The corrected result of our study clearly indicates that picoplankton production was balanced by nonoflagellate grazing and that there was a close coupling trophic relationship between picoplankton and nanoflagellate.

Acknowledgements. This study was supported by grants (NSC 101-2313-B-019-004-MY3, NSC 101-2611-M-019-015-MY3) from the National Science Council, Republic of China.

Almeida, M. A., Cunha, M. A., and Alcântara, F.: Factors influencing bacterial production in a shallow estuarine system, Microb. Ecol., 42, 416-426, 2001.

Ameryk, A., Podgórska, B., and Witek, Z.: The dependence between bacterial production and environmental conditions in the Gulf of Gdaúsk, Oceanologia., 47, 27-45, 2005.

15 Andersen, P. and Fenchel, T.: Bacterivory by microheterotrophic flagellates in seawater samples, Limnol. Oceanogr., 30, 198-202, 1985.

Azam, F., Fenchel, T., Field, J. G., Gray, J. S., Meyer-Reil, L. A., and Thingstad, F.: The ecological role of water-column microbes in the sea, Mar. Ecol. Prog. Ser., 10, 257-263, 1983.

Billen, G., Servais, P., and Becquevort, S.: Dynamics of bacteriaplankton in oligotrophic and eutrophic aquatic: bottom-up or top- down control, Hydrobiologia, 207, 37-42, 1990.

Børsheim, K. Y. and Bratbak, G.: Cell volume to cell carbon conversion factors for a bacterivorous Monas sp. enriched from seawater, Mar. Ecol. Prog. Ser., 36, 171-175, 1987.

Bouvy, M., Troussellier, M., Got, P., and Arfi, R.: Bacterioplankton responses to bottom-up and top-down control in a West African reservoir (Selingue, Mali), Aquat. Microb. Ecol., 34, 301$25307,2004$.

Calbet, A., Landry M. R., and Nunnery, S.: Bacteria-flagellate interactions in the microbial food web of the oligotrophic subtropical North Pacific, Aquat. Microb. Ecol., 23, 283-292, 2001.

Campbell, L. and Vaulot, D.: Photosynthetic picoplankton community structure in the subtropical North Pacific Ocean near Hawaii (station ALOHA), Deep-Sea Res. I, 40, 2043-2063, 1993.
BGD

10, 233-263, 2013

\section{Coupling of the spatial dynamic of picoplankton and nanoflagellate}

K.-P. Chiang et al.

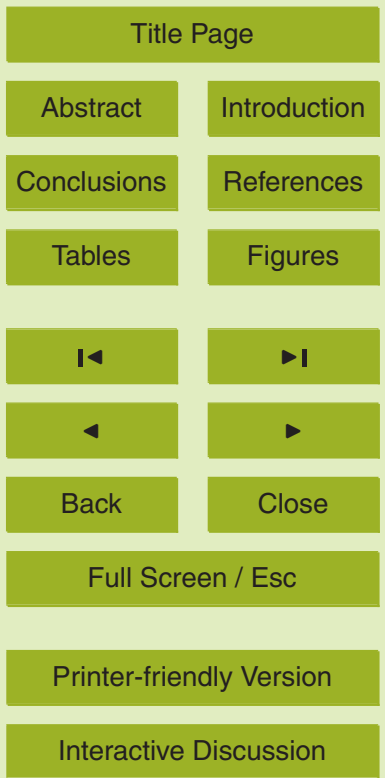


Chan, Y. F., Tsai, A. Y., Chiang, K. P., and Hsieh, C. H.: Pigmented nanoflagellates grazing on Synechococcus: Seasonal variations and effect of flagellate size in the coastal ecosystem of subtropical western Pacific, Microb. Ecol., 58, 548-557, 2009.

Christaki, U., Courties, C., Karayanni, H., Giannakourou, A., Maravelias, C., Kormas, K. A., and

5 Lebaron, P.: Dynamic characteristics of Prochlorococcus and Synechococcus consumption by bacterivorous nanoflagellates, Microb. Ecol., 43, 341-352, 2002.

Cole, J. J. and Caraco, N. F.: The pelagic food web of oligotrophic lakes, in: Aquatic Microbiology, edited by: Ford, T. E., Blackwell Publishing, New York, 101-111, 1993.

Duarte, C. M. and Agustí, S.: Experimental test of bacteria-phytoplankton coupling in the Southern Ocean, Limnol. Oceanogr., 50, 1844-1854, 2005.

Ducklow, H. W.: Production and fate of bacteria in the oceans, Bioscience, 33, 494-501, 1983.

Ducklow, H. W.: Factors regulating bottom-up control of bacterial biomass in open ocean plankton community, Arch. Hydrobiol. Beih. Ergebn. Limnol., 37, 207-217, 1992.

Fenchel, T.: Ecology of heterotrophic microflagellate, II, Bioenergetics and growth, Mar. Ecol.

15 Prog. Ser., 8, 225-231,1982.

Ferrier-Pagés, C. and Gattuso J. P.: Biomass, production and grazing rates of pico- and nanoplankton in coral reef waters (Miyako Island, Japan), Microb. Ecol., 35, 46-57, 1998.

Gasol, J. M.: A framework for the assessment of top-down vs bottom-up control of heterotrophic nanoflagellate abundance, Mar. Ecol. Prog. Ser., 113, 291-300, 1994.

20 Gasol, J. M. and Duarte, C. M. Comparative analyses in aquatic microbial ecology: how far do they go, FEMS Microbiol. Ecol., 31, 99-106, 2000.

Gasol, J. M., Pedrós-Alió, C., and Vaqué, D.: Regulation of bacterial assemblages in oligotrophic plankton system: results from experimental and empirical approaches, Anton. Leeuw., 81, 435-452, 2002.

Gong, G. C., Shyu, C. Z., Shih, W. H., and Liu, K. K.: Temperature of the cold water off northern Taiwan: June-December, 1990, Acta Oceanographica Taiwanica, 28, 118-127, 1992.

Gong, G. C., Chen, L.Y. L., and Liu, K. K.: Chemical hydrography and chlorophyll a distribution in the East China Sea in summer: implications in nutrient dynamics, Cont. Shelf Res., 16, 1561-1590, 1996.

30 Goosen, N. K., Rijswijk P. V., Bie, M. D., Peene J., and Kromkamp J.: Bacterioplankton abundance and production and nanozooplankton abundance in Kenyan coastal waters (Western Indian Ocean), Deep Sea Res., 44, 1235-1250, 1997.

BGD

10, 233-263, 2013

\section{Coupling of the spatial dynamic of picoplankton and nanoflagellate}

K.-P. Chiang et al.

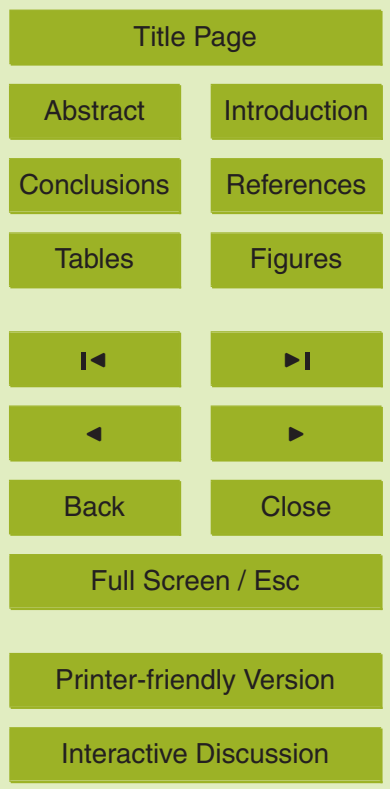


Granda, A. and Álvarez, R. A.: The annual cycle of nanoflagellates in the central Cantabrian Sea (Bay of Biscay), J. Mar. Syst., 72, 298-308, 2008.

Hahn, M. W. and Hofle, M. G.: Grazing of protozoa and its effect on populations of aquatic bacteria, FEMS Microbiol Ecol., 35, 113-121, 2001.

5 Hairston, N. G., Smith, F. E., and Slobodkin, L. B.: Community structure, population control and competition, Am. Nat., 94, 421-425, 1960.

Hirose, M., Katano, T., and Nakano S. I.: Geowth and grazing mortality rates of Prochlorococcus, Synechococcus and eukaryotic picophytoplankton in a bay of the Uwa Sea, Japan. J. Plankton Res., 30, 241-250, 2008.

10 Hoch, M. and Kirchman, D. L.: Seasonal and inter-annual variability in bacterial production and biomass in a temperate estuary, Mar. Ecol. Prog. Ser., 98, 283-295, 1993.

Iriarte, A., Sarobe, A., and Orive, E.: Seasonal variability in bacterial abundance, production and protistan bacterivory in the lower Urdaibai estuary, Bay of Biscay, Aquat. Microb. Ecol., 52, 273-282, 2008.

15 Jochem, F.: Photo- and heterotrophic pico- and nanoplankton in the Mississippi River plume: distribution and grazing activity, J. Plankton Res., 25, 1201-1214, 2003.

Kobari, T., Fujii, T., Kobari, Y., and Habano, A.: Seasonal variation in abundance, growth and morality of heterotrophic bacteria in Kagoshima Bay, J. Oceanogr., 66, 845-853, 2010.

Lee, S. and Fuhrman, J. A.: Relationship between biovolume and biomass of naturally derived marine bacterioplankton, Appl. Environ. Microbiol., 53, 1298-1303, 1987.

Lee, C. W., Kudo, I., Yanada, M., and Maita, Y.: Bacterial abundance and production and heterotrophic nanoflagellate abundance in subarctic coastal waters (western North Pacific Ocean), Aquat. Microb. Ecol., 23, 263-271, 2001.

Li, W. K. W., Rao, D. V. S., Harrison, W. G., Smith, J. C., Cullen, J. J., Irwin, B., and Platt, T.: $25 \quad$ Autotrophic picoplankton in tropical ocean, Science, 219, 292-295, 1983.

Lin, Y. C., Tsai, A. Y., and Chiang, K. P.: Trophic coupling between Synechococcous and pigmented nanoflagellate in the coastal waters of Taiwan, western subtropical Pacific, J. Oceanogr., 65, 781-789, 2009.

Marie, D., Partensky, F., Jacquet, S., and Vaulot, D.: Enumeration and cell cycle analysis of 30 natural populations of marine picoplankton by flowcytometry using the nucleic acid stain SYBR Green I, Appl. Environ. Microbiol., 63, 186-193, 1997.

Murrell, M. C.: Bacterioplankton dynamics in a subtropical estuary: evidence for subtrate limitation, Aquatic. Microb. Ecol., 32, 239-250, 2003.
BGD

10, 233-263, 2013

\section{Coupling of the spatial dynamic of picoplankton and nanoflagellate}

K.-P. Chiang et al.

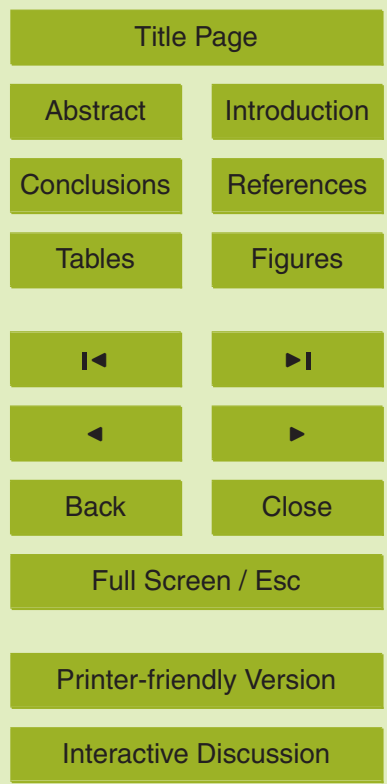


Pace, M. L.: The problem of bacterial death rates, Hydrobiologia, 159, 41-49, 1988.

Pomeroy, L. R .: The ocean's food web, a changing paradigm, Bioscience, 24, 499-504, 1974.

Porter, K. G. and Feig, Y. S.: The use of DAPI for identifying and counting aquatic microflora, Limnol. Oceanogr., 25, 943-948, 1980.

5 Sanders, R. W., Caron, D. A., and Berniger, U. G.: Relationships between bacteria and heterotrophic nanoplankton in marine and fresh water: an inter-ecosystem comparison, Mar. Ecol. Prog. Ser., 86, 1-14, 1992.

Sanders, R. W., Berninger, U. G., Lim, E. L., Kemp, P. F., and Caron, D. A.: Heterotrophic and mixotrophic nanoplankton predation on picoplankton in the Sargasso Sea and on Georges 10 Bank, Mar. Ecol. Prog. Ser., 192, 103-118, 2000.

Schultz Jr., G. E., White III, E. D., and Ducklow, H. W.: Bacterioplankton dynamics in the York River estuary: primary influence of temperature and freshwater input, Aquat. Microb. Ecol., 30, 135-148, 2003.

Shen, M. L., Tseng, Y. H., and Jan, S.: The formation and dynamics of the cold-dome off northeastern Taiwan, J. Mar. Syst., 86, 10-27, 2011.

Sherr, E. B. and Sherr, B. F.: Bacterivory and herbivory: key roles of phagotrophic protists in pelagic food webs, Microb. Ecol., 28, 223-235, 1994.

Shiah, F. K. and Ducklow, H. W.: Bacterioplankton growth responses to temperature and chlorophyll variations in estuaries measured by thymidine: leucine incroporation ratio, Aquat. Microb. Ecol., 13, 151-159, 1997.

Simerk, K., Bobkova, J., Macek, M., Nedoma, J., and Psenner, R.: Ciliate grazing on picoplankton in a eutrophic reservoir during the summer phytoplankton maximum: a study at the species and community level, Limnol. Oceanogr., 40, 1077-1090, 1995.

Taira, Y., Uchimiya, M., and Kudo, I.: Simultaneous estimation of viral lysis and protozoan grazing on bacterial mortality using a modified virus-dilution method, Mar. Ecol. Prog. Ser., 379, 23-32, 2009.

Tanaka, T. and Taniguchi, A.: Predator-prey eddy in heterotrophic nanoflagellate-bacteria relationships in a bay on the northeastern Pacific coast of Japan, Mar. Ecol. Prog. Ser., 179, 123-134, 1999.

so Tanaka, T., Fujita, N., and Taniguchi, A.: Predator-prey eddy in heterotrophic nanoflagellatebacteria relationships in a coastal marine environment: a new scheme for predator-prey associations, Aquat. Microb. Ecol., 13, 249-256, 1997.
BGD

10, 233-263, 2013

\section{Coupling of the spatial dynamic of picoplankton and nanoflagellate}

K.-P. Chiang et al.

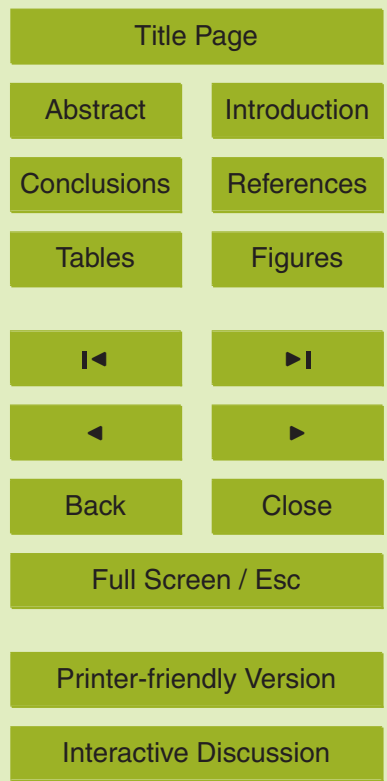


Thingstad, T.: Control of bacterial growth in idealized food web, in: Microbial Ecology of the Ocean, edited by: Kirchman, D. L., John Wiley and Sons, New York, 229-260, 2000.

Tsai, A. Y., Chiang, K. P., Chang, J., and Gong, G. C.: Seasonal diel variations of picoplankton and nanoplankton in a subtropicalwestern Pacific coastal ecosystem, Limnol. Oceanogr., 50, 5 1221-1231, 2005.

Tsai, A. Y., Chiang, K. P., Chan, Y. F., Lin, Y. C., and Chang, J.: Pigmented nanoflagellates in the coastal western subtropical Pacific are important grazers on Synechococcus populations, J. Plankton Res., 29, 71-77, 2007.

Tsai, A. Y., Chiang, K. P., Chang, J., and Gong, G. C.: Seasonal variations in trophic dynamics of nanoflagellates and picoplakton in coastal waters of the western subtropical Pacific Ocean, Aquat. Microb. Ecol., 51, 263-274, 2008.

Tsai, A. Y., Gong, G. C., Sander, R. W., Chao C. F., and Chiang, K.-P.: Microbial dynamics in an oligotrophic Bay of the western subtropical Pacific: impact of short-term heavy freshwater runoff and upwelling, J. Oceanogra., 66, 873-883, 2010.

Tsai, A. Y., Gong, G. C., Sander, R. W., Chen, W. H., Chao C. F., and Chiang, K.-P.: Importance of bacterivory by pigmented and heterotrophic nanoflagellate during the warm season in a subtropical western Pacific coastal ecosystem, Aquat. Microb. Ecol., 63, 9-18, 2011.

Vaqué, D., Calderón-Paz, J. I., Guixa-Boixereu, N., and Pedrós-Alió, C.: Spatial distribution of microbial biomass and activity (bacterivory and bacterial production) in the northern Weddell

20 Sea during the austral summer (January 1994), Aquatic. Microb. Ecol., 29, 107-121, 2002.

White, P. A., Kalff, J., Rasmussen, J. B., and Gasol, J. M.: The effect of temperature and algal biomass on bacterial production and specific growth rate in freshwater and marine habitats, Microb. Ecol., 21, 99-118, 1991.

Wikner, J. and Hagström, Å.: Annual study of bacterioplankton community dynamics, Limnol. 25 Oceanogr., 36, 1313-1324, 1991.

Wilhelm, S. W., Brigden, S. M., and Suttle, C. A.: A dilution technique for the direct measurement of viral production: a comparison in stratified and tidally mixed coastal waters, Microb. Ecol., 43, 168-173, 2002.

Wright, R. T. and Coffin, R. B.: Measuring microzooplankton grazing on planktonic marine bacteria by its impact on bacterial production, Microb. Ecol., 10, 137-149, 1984.

Zubkov, M. V., Sleigh, M. A., Burkill P. H., and Leakey, R. J. G.: Bacterial growth and grazing loss in contrasting areas of North and South Atlantic, J. Plankton Res., 22, 685-711, 2000.

\section{Coupling of the spatial dynamic of picoplankton and nanoflagellate}

K.-P. Chiang et al.

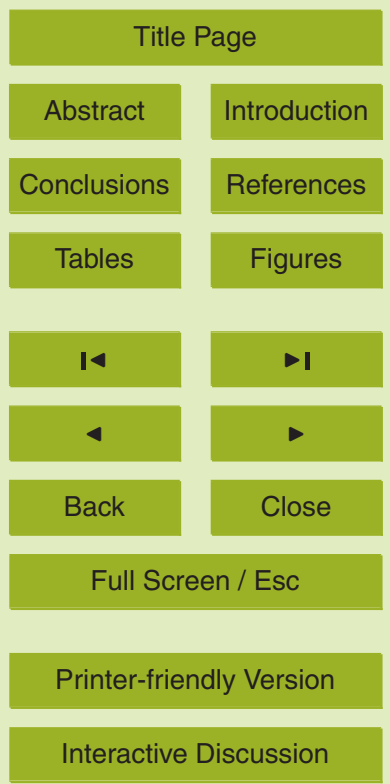




\section{BGD}

$10,233-263,2013$

Table 1. The surface temperature, salinity, $\mathrm{NO}_{3}$, and $\mathrm{Chl} a$, as well as the abundance and biomass of bacteria, Synechococcus spp. and total nanoflagellate.

\begin{tabular}{|c|c|c|c|c|c|c|}
\hline & & 2-5 Aug 2010 & 23-25 Aug 2010 & 8-10 Jun 2011 & 1-3 Aug 2011 & 4-6 Sep 2011 \\
\hline$T\left(^{\circ}\right)$ & & $27.1 \pm 1.4$ & $28.7 \pm 0.7$ & $25.0 \pm 0.9$ & $28.3 \pm 0.7$ & $26.5 \pm 2.4$ \\
\hline$S$ (psu) & & $33.9 \pm 0.3$ & $33.8 \pm 0.1$ & $33.7 \pm 0.8$ & $33.7 \pm 0.2$ & $33.9 \pm 0.3$ \\
\hline $\mathrm{NO}_{3}(\mu \mathrm{M})$ & & $0.025 \pm 0.05$ & $0.27 \pm 0.75$ & $0.21 \pm 0.52$ & $0.07 \pm 0.16$ & $0.59 \pm 0.94$ \\
\hline $\mathrm{Chl} a\left(\mathrm{mg} \mathrm{m}^{-3}\right)$ & & $0.89 \pm 0.69$ & $0.39 \pm 0.42$ & $1.57 \pm 2.18$ & $0.32 \pm 0.13$ & $0.96 \pm 1.02$ \\
\hline Bacteria & abun. & $3.0 \pm 1.4$ & $10.5 \pm 7.3$ & $6.2 \pm 6.1$ & $13.9 \pm 3.7$ & $18.7 \pm 9.2$ \\
\hline & bio. & $7.6 \pm 3.8$ & $22.3 \pm 13.7$ & $12.4 \pm 12.2$ & $27.9 \pm 7.3$ & $37.3 \pm 18.3$ \\
\hline Syn. & abun. & $72.1 \pm 117.4$ & $59.9 \pm 54.0$ & $52.3 \pm 34.5$ & $25.1 \pm 28.8$ & $67.0 \pm 85.0$ \\
\hline & bio. & $18.8 \pm 29.0$ & $16.2 \pm 14.0$ & $13.1 \pm 8.6$ & $6.3 \pm 7.2$ & $16.8 \pm 21.3$ \\
\hline TNF & $\begin{array}{l}\text { abun. } \\
\text { bio. }\end{array}$ & $\begin{array}{l}674.2 \pm 227.4 \\
3.2 \pm 2.1\end{array}$ & $\begin{array}{l}715.9 \pm 169.7 \\
3.6 \pm 1.3\end{array}$ & $\begin{array}{l}569.3 \pm 206.2 \\
6.7 \pm 2.8\end{array}$ & $\begin{array}{l}322.1 \pm 114.2 \\
3.8 \pm 2.2\end{array}$ & $\begin{array}{l}300.9 \pm 146.9 \\
3.8 \pm 2.8\end{array}$ \\
\hline
\end{tabular}

All data were taken from Sea Bird CTD-General Oceanic Rosette assembly with 20 L Go-Flo bottles from the surface water. $T$, temperature; $S$, salinity; Syn., Synechococcus; TNF, total nanoflagellate; abun., abundance ( $10^{5}$ cells $\mathrm{mL}^{-1}$ in bacteria and $10^{3}$ cells $\mathrm{mL}^{-1}$ in Synechococcus); bio., biomass $\left(\mu \mathrm{g} \mathrm{CL}^{-1}\right)$.

\section{Coupling of the spatial dynamic of picoplankton and nanoflagellate}

K.-P. Chiang et al.

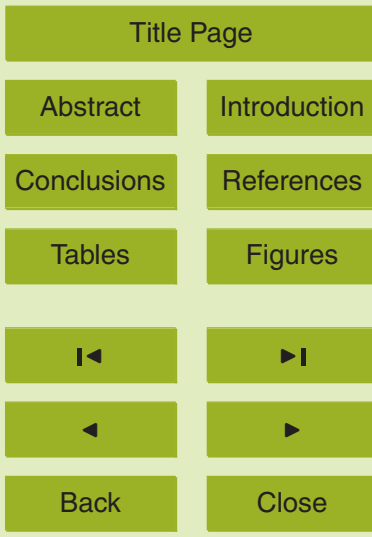

Full Screen / Esc

Printer-friendly Version

Interactive Discussion 
BGD

$10,233-263,2013$

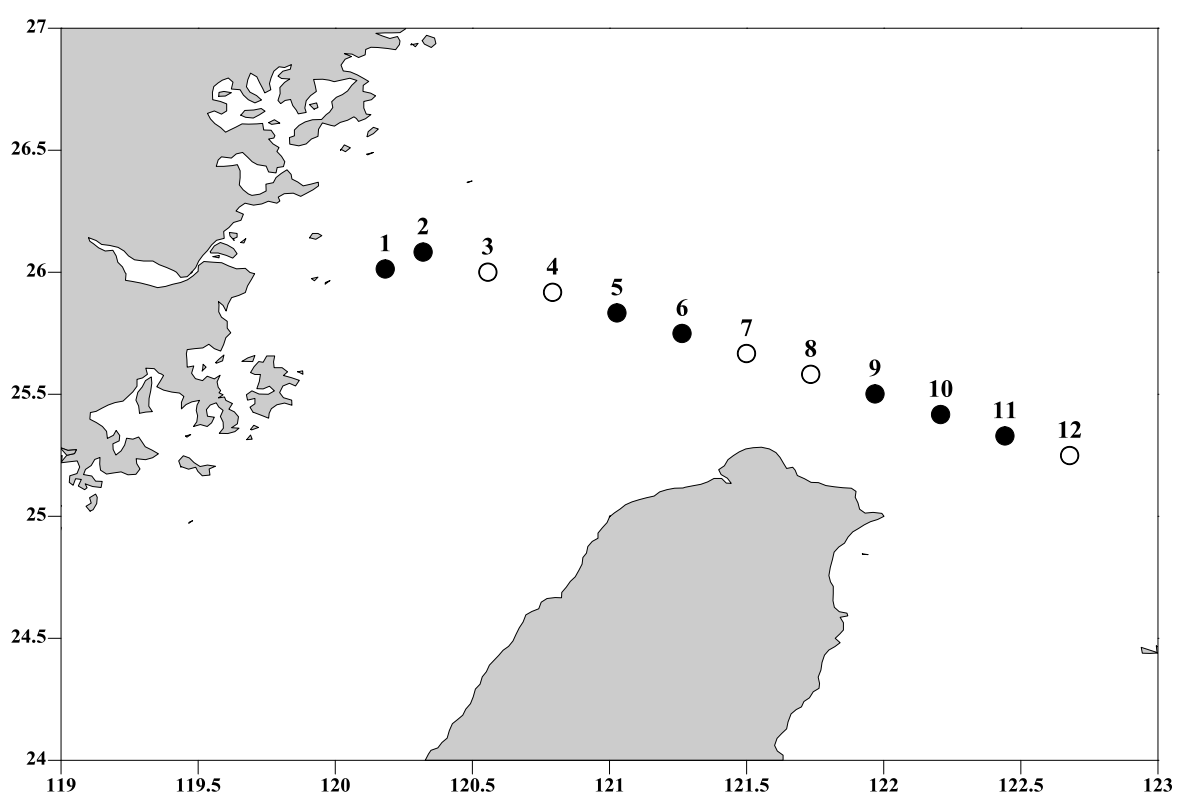

Fig. 1. Sampling stations 1-12 were located along a cross-shelf transect in the southern East China Sea on the five cruises of present study during the summer period of 2010 and 2011. Solid circles indicate the stations where culture experiments with fractionation method were performed.

\section{Coupling of the spatial dynamic of picoplankton and nanoflagellate}

K.-P. Chiang et al.

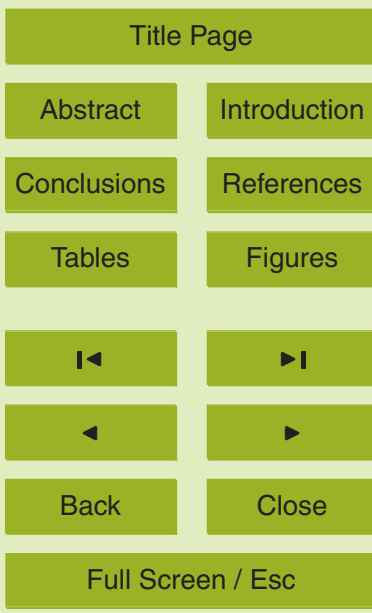

Printer-friendly Version

Interactive Discussion 


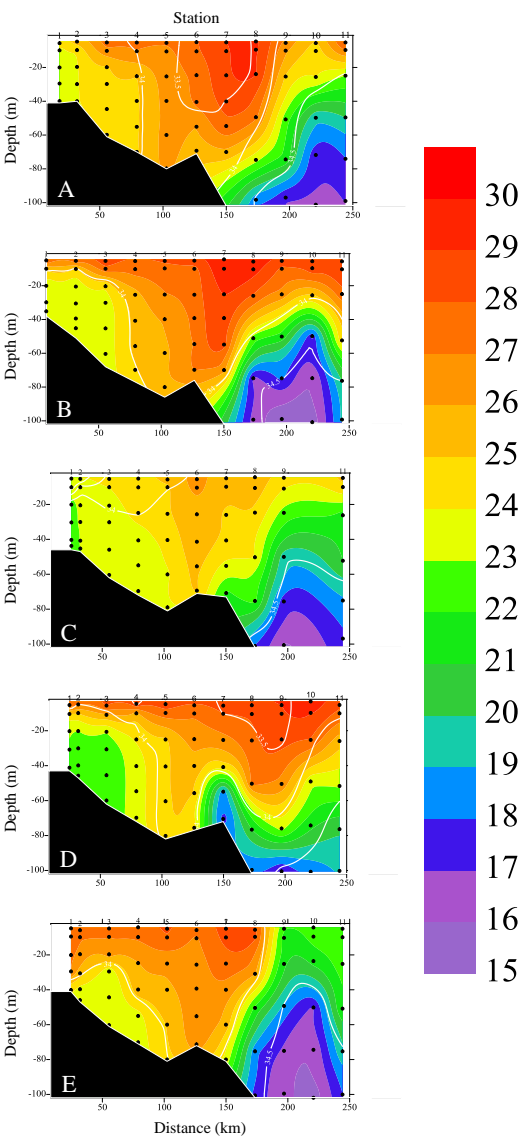

Fig. 2. Vertical profiles of temperature $\left({ }^{\circ} \mathrm{C}\right)$ and salinity (psu, solid line) along a cross-shelf transect on (A) 2-5 August 2010, (B) 23-25 August 2010, (C) 8-10 June 2011, (D) 1-3 August 2011 and (E) 4-6 September 2011.

\section{BGD}

10, 233-263, 2013

\section{Coupling of the} spatial dynamic of picoplankton and nanoflagellate

K.-P. Chiang et al.

\section{Title Page}

\section{Abstract}

Conclusions

Tables

14

$\triangleleft$

Back

\section{Full Screen / Esc}

Printer-friendly Version 


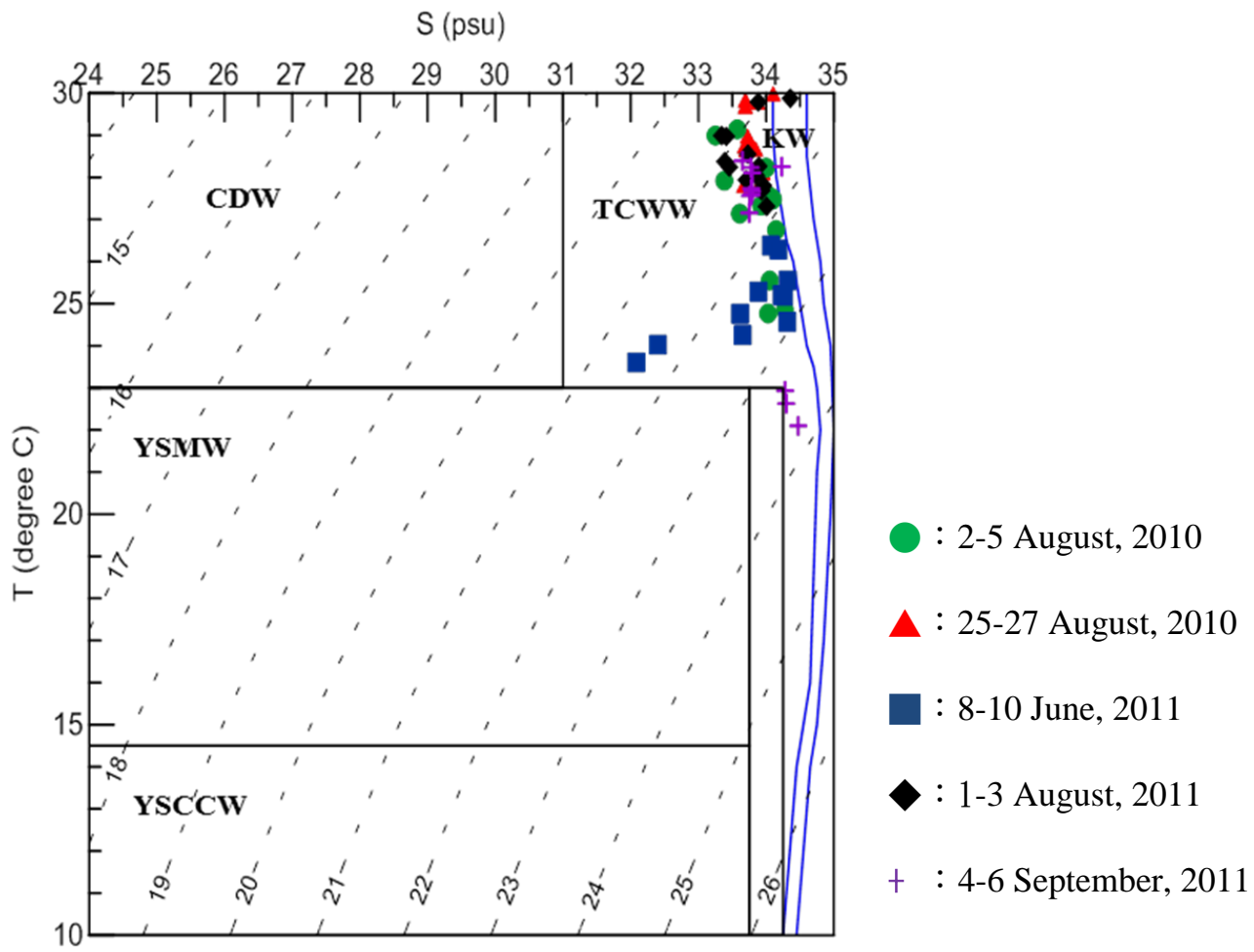

Fig. 3. The surface $T-S$ relationship of sea water in the five cruises of present study. CDW, Chiangjiang Diluted Water; KW, Kuroshio Water; TCWW, Taiwan Current Warm Water; YSCW, Yellow Sea Cold Water; YSMW, Yellow Sea Mixed Water.
BGD

10, 233-263, 2013

Coupling of the spatial dynamic of picoplankton and nanoflagellate

K.-P. Chiang et al.

Title Page

Abstract

Introduction

Conclusions

References

Tables

Figures

14

4

Back

Close

Full Screen / Esc

Printer-friendly Version

Interactive Discussion 

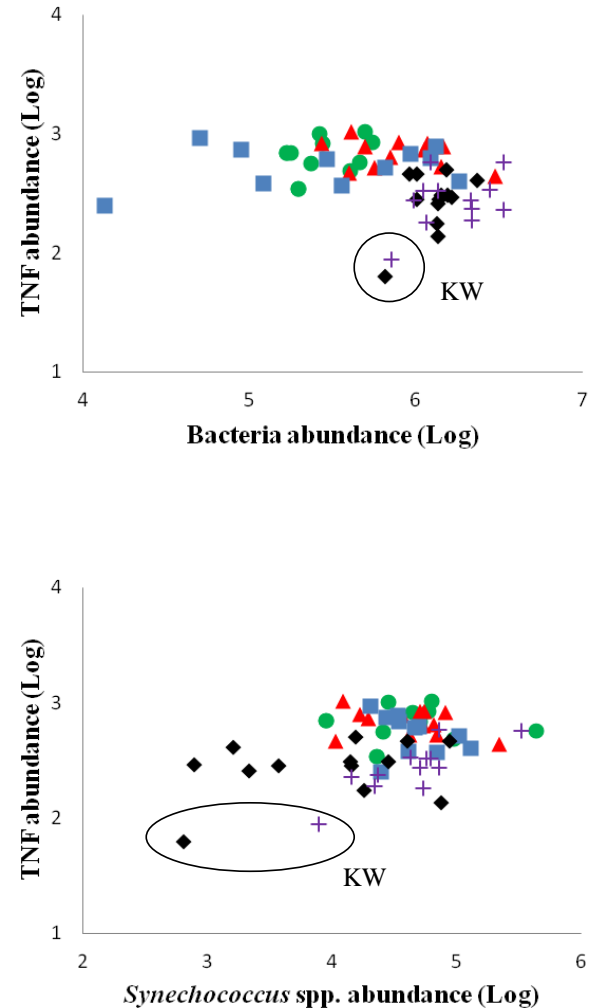

- $2010 / 8 / 2-5$

- 2011/6/8-10

-2011/8/1-3

$+2011 / 9 / 4-6$
A 2010/8/23-25

BGD

10, 233-263, 2013

\section{Coupling of the spatial dynamic of picoplankton and nanoflagellate}

K.-P. Chiang et al.

\section{Title Page}

\section{Abstract} Introduction

Conclusions

References

Tables

Figures

14

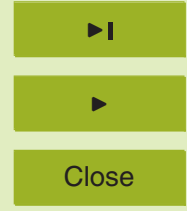

Back

Full Screen / Esc

Fig. 4. The spatial relationship between the abundance of total nanoflagellate and picoplankton and abundance of (A) bacteria and (B) Synechococcus spp. for the surface of all stations in the five cruises of the present study. KW, Kurashio Water; TNF, total nanoflagellate.
Printer-friendly Version

Interactive Discussion 


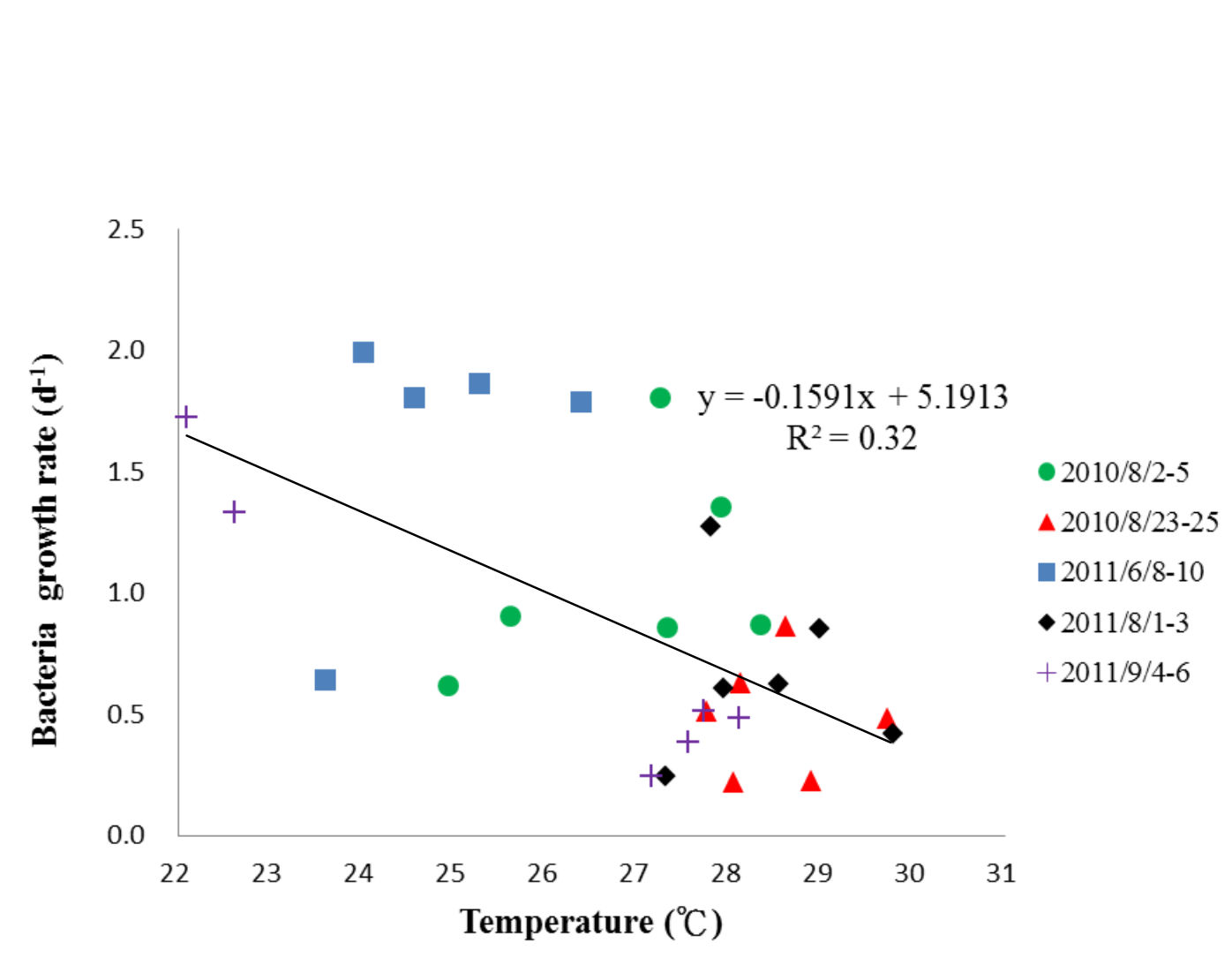

Fig. 5. The relationship between specific growth rate of bacteria and temperature of surface water at culture experiment stations.

BGD

10, 233-263, 2013

\section{Coupling of the spatial dynamic of picoplankton and nanoflagellate}

K.-P. Chiang et al.

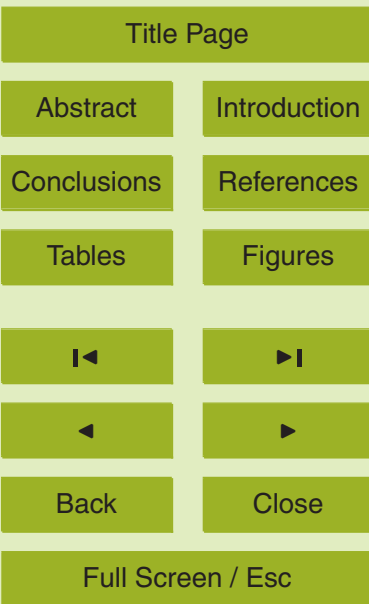

Printer-friendly Version

Interactive Discussion 


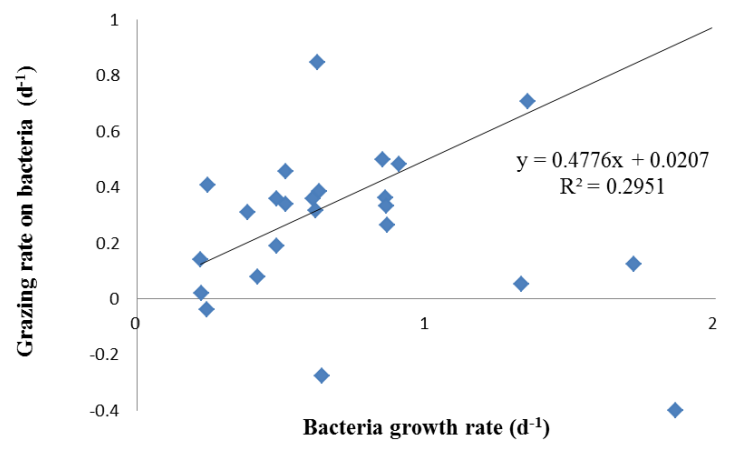

BGD

10, 233-263, 2013

\section{Coupling of the spatial dynamic of picoplankton and nanoflagellate}

K.-P. Chiang et al.

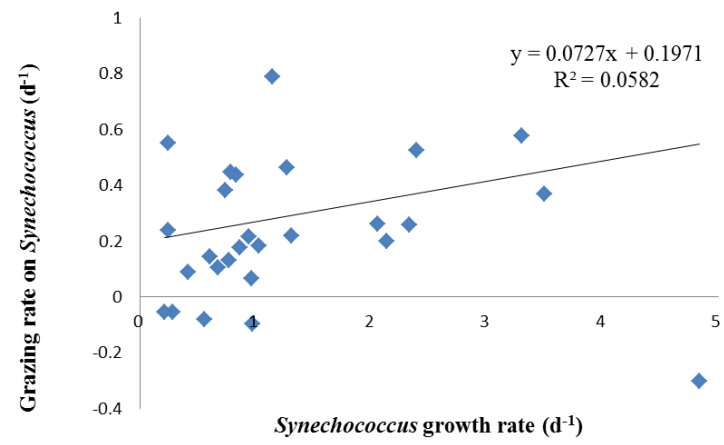

B

Title Page

Abstract

Conclusions
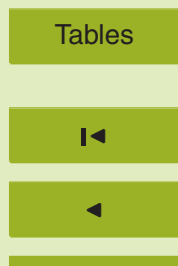

Back

Full Screen / Esc

Printer-friendly Version

Interactive Discussion Fig. 6 . The relationship between picoplanktonal specific growth
rate on picoplankton. (A) Bacteria and (B) Synechococcus spp. 


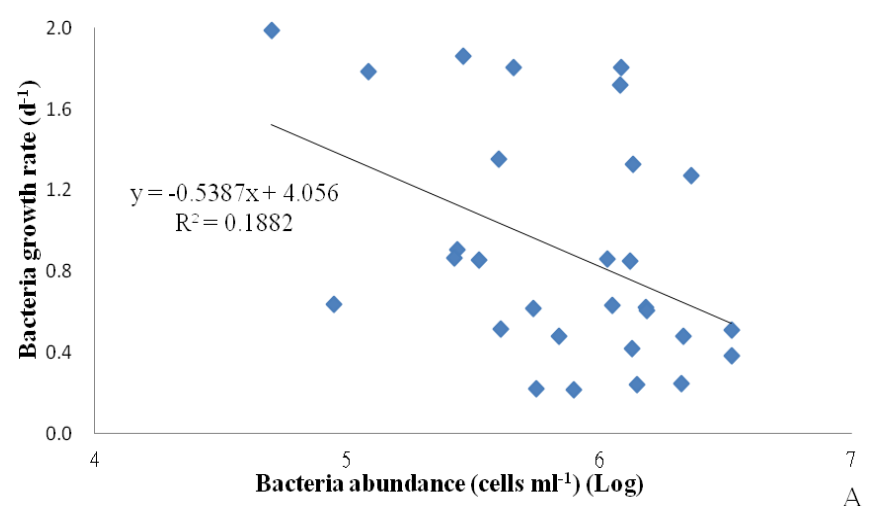

BGD

10, 233-263, 2013

\section{Coupling of the spatial dynamic of picoplankton and nanoflagellate}

K.-P. Chiang et al.

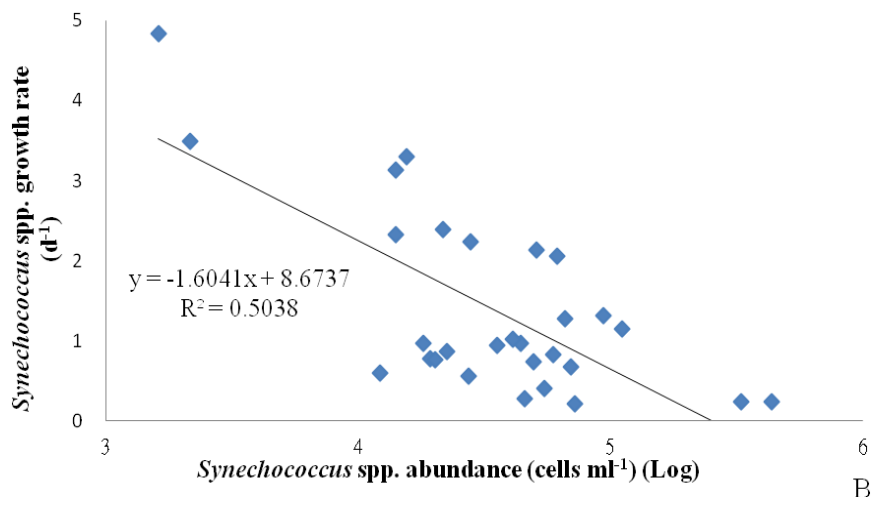

Title Page

Abstract

Conclusions
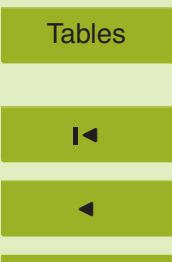

Back
Introduction

References

Figures

$>$ I

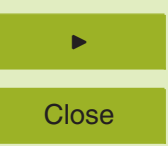

Full Screen / Esc

Printer-friendly Version

Interactive Discussion 


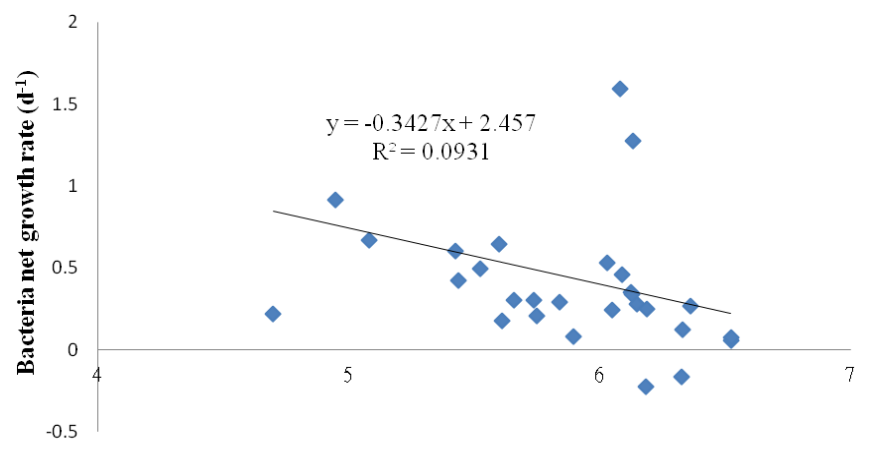

BGD

10, 233-263, 2013

\section{Coupling of the spatial dynamic of picoplankton and nanoflagellate \\ K.-P. Chiang et al.}

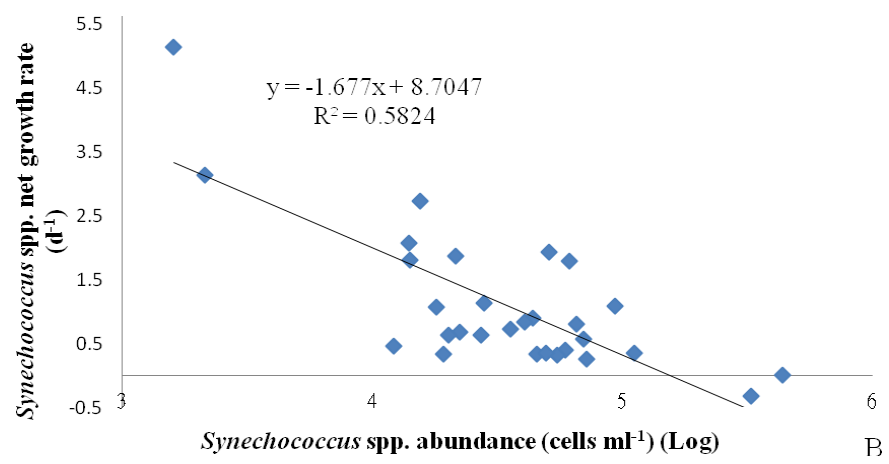

Title Page

Abstract

Conclusions
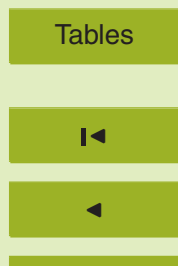

Back
Introduction

References

Figures

$>1$

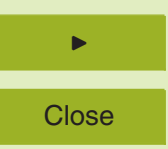

Full Screen / Esc

Printer-friendly Version

Fig. 8. The relationship between net growth rate and abundance of picoplankton. (A) Bacteria; (B) Synechococcus spp. 


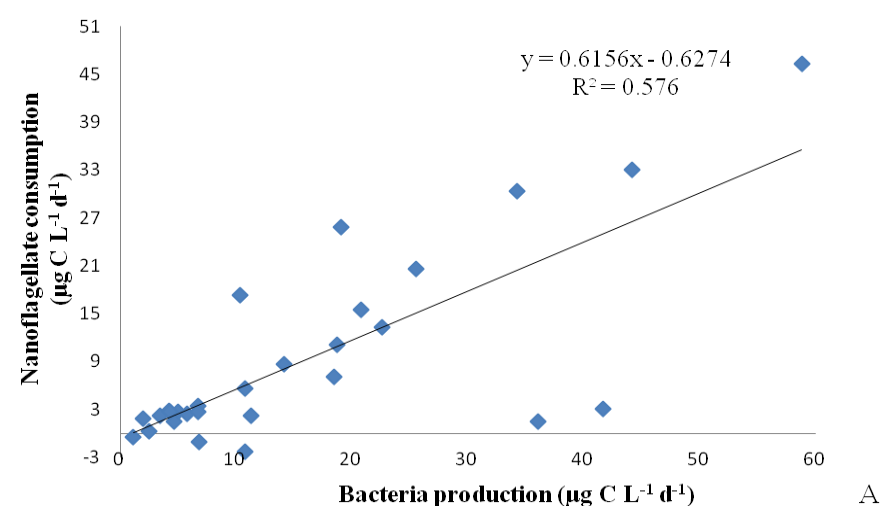

BGD

$10,233-263,2013$

\section{Coupling of the spatial dynamic of picoplankton and nanoflagellate}

K.-P. Chiang et al.

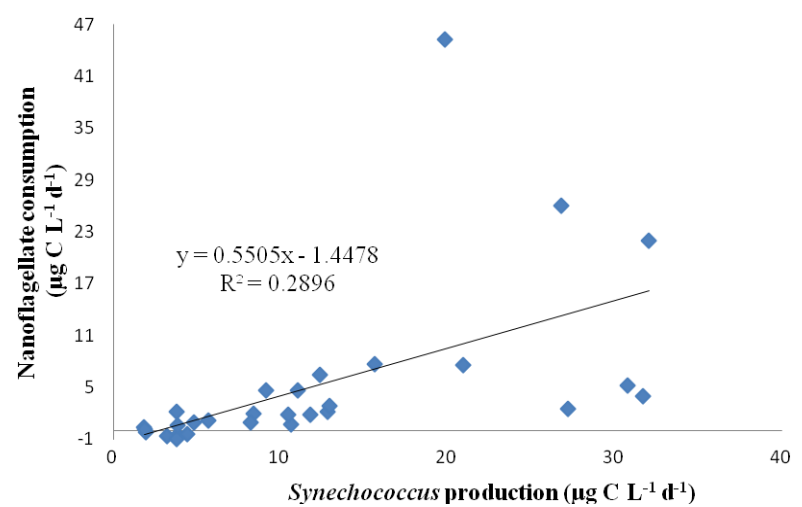

$\mathrm{B}$

Fig. 9. The relationship between nanoflagellate consumption rate on picoplankton and picoplankton production rate. (A) Bacteria; (B) Synechococcus spp.

Title Page

Abstract

Introduction

Conclusions

References

Tables

Figures

14

$\rightarrow$ I

\section{$<$}

Back

Close

\section{Full Screen / Esc}

Printer-friendly Version

Interactive Discussion 


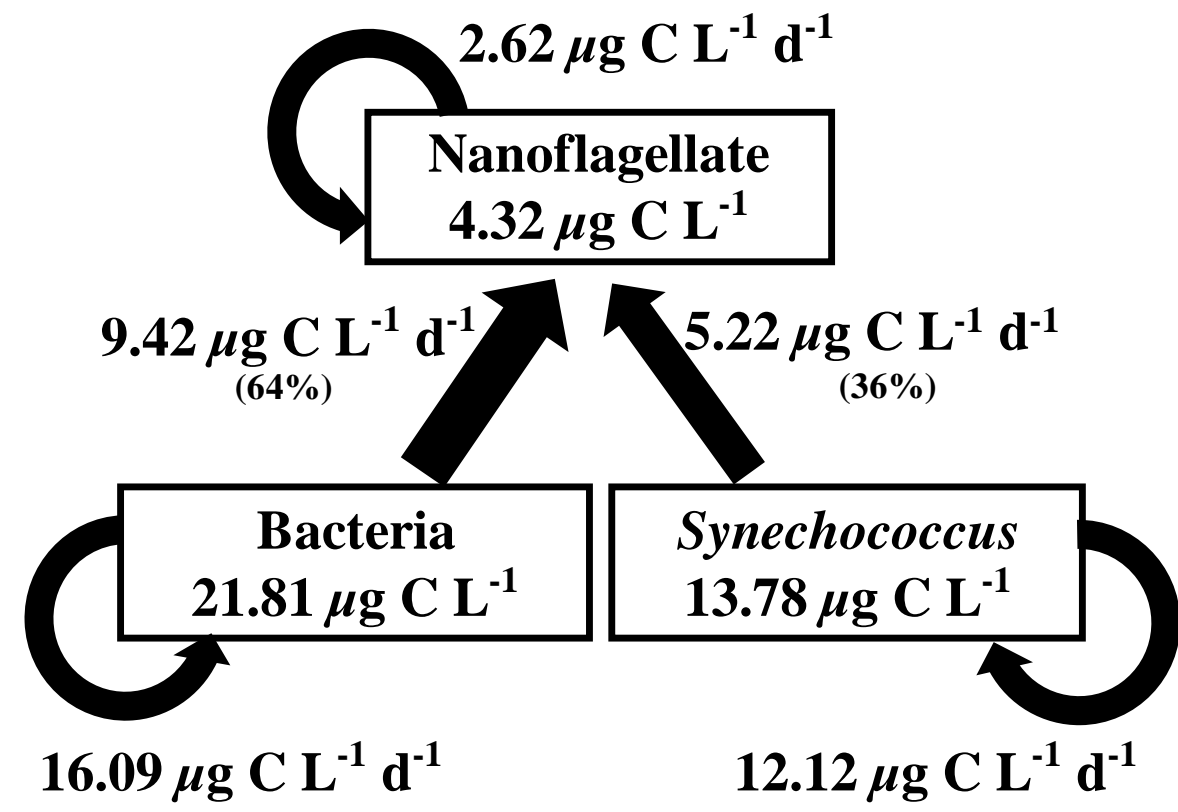

$C L^{-1} d^{-1}$

Nanoflagellate $4.32 \mu \mathrm{g} \mathrm{C} \mathrm{L}^{-1}$

Fig. 10. Schematic carbon flow diagram depicting warm seasonal variation in energy transfer of picoplankton production to nanoflagellates in oligotrophic Taiwan Current Warm Water, the Subtropical Pelagic Continental Shelf Ecosystem. The numbers within individual picoplankton and nanoflagellates boxes refer to their biomass. The numbers next to looped arrow represent picoplankton production rate $\left(\mu \mathrm{g} \mathrm{CL}^{-1} \mathrm{~d}^{-1}\right)$. Straight arrow pointing to nanoflagellate show their grazing rate $\left(\mu \mathrm{gCL}^{-1} \mathrm{~d}^{-1}\right)$.

\section{BGD}

10, 233-263, 2013

\section{Coupling of the spatial dynamic of picoplankton and nanoflagellate \\ K.-P. Chiang et al.}

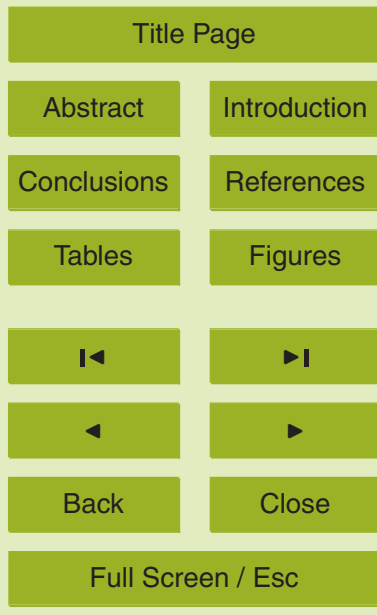

Printer-friendly Version

Interactive Discussion 

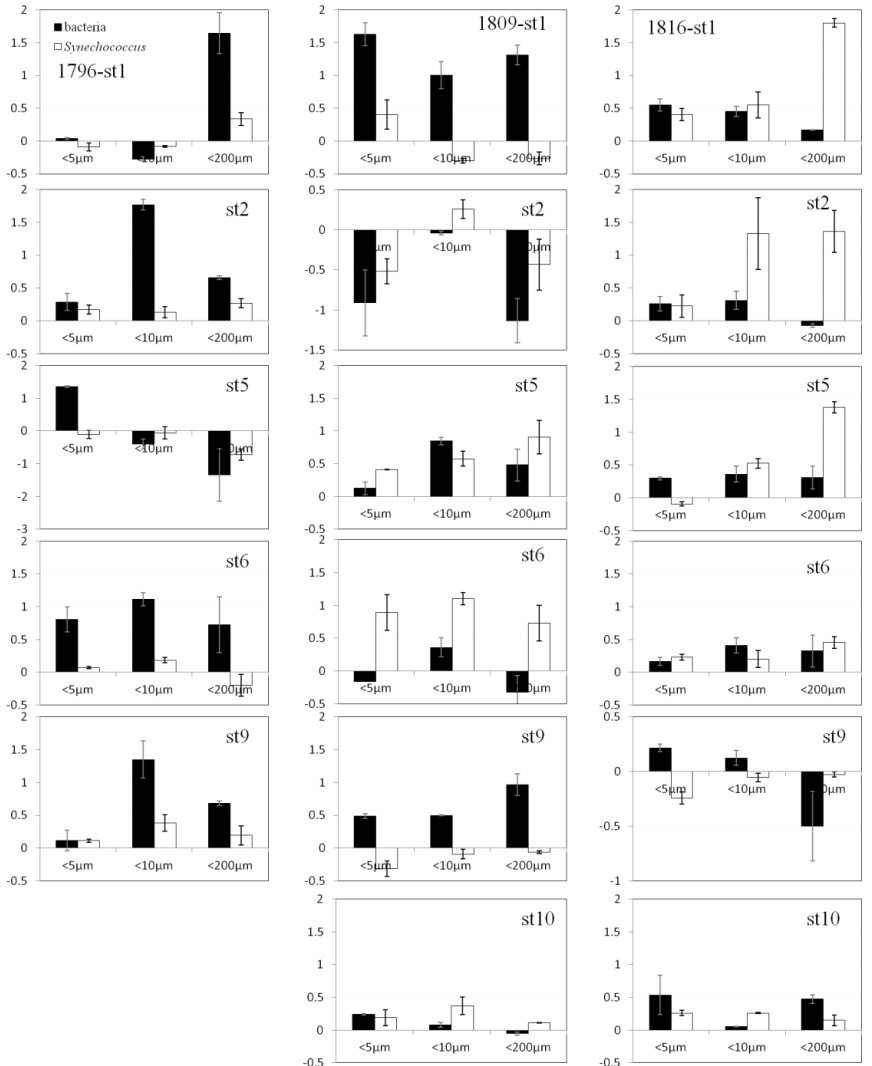

Fig. 11. Effect of removing different size classes of picoplankton. Treatments of seawater samples filtered through 5,10 and $200 \mu \mathrm{m}$ filters. The unit on y-axis is $\mathrm{d}^{-1}$.
BGD

10, 233-263, 2013

Coupling of the spatial dynamic of picoplankton and nanoflagellate

K.-P. Chiang et al.

Title Page

Abstract

Introduction

Conclusions

References

Tables

Figures

14

$>$ I

4

Back

Close

\section{Full Screen / Esc}

Printer-friendly Version

Interactive Discussion 